\title{
Chapter 1 \\ Microbial Growth and its Effects on Inorganic Heritage Materials
}

\author{
Daniela Pinna
}

\begin{abstract}
Cultural heritage objects composed of inorganic materials, such as metals and stones, support microbial life. Many factors affect the growth of microorganisms: moisture, $\mathrm{pH}$, light, temperature, nutrients. Their colonization relates closely to the nature of the substrata as well as to the characteristic of the surrounding environment. This chapter contains an overview of the complex relationships among microbial growth, materials, and the environment. It emphasizes issues on bioreceptivity of stones and the factors influencing biological colonization, focusing on the biological alteration of inorganic heritage objects and on the agents of biodeterioration. It outlines the effect of biofilms and lichens in terms of degradation of substrata and includes a discussion on an important topic, the bioprotection of stones by biofilms and lichens. In summary, this chapter aims to discuss these issues and review the recent literature on (i) biofilms and lichens colonizing inorganic materials, (ii) the limiting factors of this colonization, (iii) the deteriorative aspects, and (iv) the protective effects of the colonization.
\end{abstract}

Keywords Biofilms $\cdot$ Lichens $\cdot$ Stone bioreceptivity $\cdot$ Substratum pH ·

Eutrophication $\cdot$ Environmental factors $\cdot$ Biodeteriorative processes of stones, metals and stained-glass windows $\cdot$ Bioprotection of stones by biofilms and lichens

\section{Introduction}

Cultural heritage objects that are composed of inorganic materials, such as metals and stones, support microbial life. Bacteria, algae, fungi, lichens colonize the surfaces of historic buildings, archaeological sites, stone and metal sculptures, rock art sites, caves, catacombs. Microbial growth has been detected on wall paintings, ceramics, mosaics, glass, mortars, concrete. Many factors affect the

\footnotetext{
D. Pinna $(\triangle)$

Department of Chemistry, University of Bologna, Bologna, Italy

e-mail: daniela.pinna@unibo.it
} 
colonization of microorganisms: moisture, $\mathrm{pH}$, light, temperature, nutrients. Variable ecological spatial patterns can occur on monuments because of changes in these environmental factors. When a microbial colonization is evident, its relevance to degradation and weathering of inorganic materials should be carefully evaluated as biotic and abiotic agents interact in quantitatively variable relations (Siegesmund and Snethlage 2014). The detection of organisms on cultural objects does not indicate necessarily that they are modifying the chemical composition or physical properties of the materials (Pinna 2017). Only in particular conditions and in combination with other factors they can initiate, facilitate, or accelerate deterioration processes. Moreover, the growth of some organisms is very slow, and the damage becomes visible only after years or even decades.

At present, the importance of biodeterioration processes on historical objects of art has reached growing attention of people in charge of the conservation of cultural heritage. A large set of relevant studies have documented and discussed the interaction between biological colonization and cultural heritage objects. Despite considerable research efforts, there are still general issues that need to be addressed. Regarding stones, many aspects of the interaction between microbial communities, lichens and these materials are still unknown (Di Martino 2016). Not surprisingly, in recent times many papers report that the biological colonization of outdoor stones may act as a protective layer shielding the materials from other factors that cause decay, such as wind and rainwater. In addition, the species and their amount within biofilm-forming microbial communities can change over time. Progress in microbial ecology and genomics, in parallel with developments in biological imaging and analytical surface techniques, can promote a comprehensive insight into the dynamics of the structured microbial community within biofilms. This evidence will contribute to foresee their responses after short- and long-term disturbances and in future changes of environmental conditions.

Regarding metals, the importance of microbial ecology in microbiologically influenced corrosion (i.e. the differences between actively corroding and non-corroding microbes present on metals exposed in the same environment) and the effect of the biofilm matrix on the electrochemical behavior of metals are issues that need to be further examined. Elucidating them will also facilitate the development of more efficient prevention and protection measures.

This chapter aims to discuss these issues and review the recent literature on (i) biofilms and lichens colonizing inorganic materials, (ii) the limiting factors of this colonization, (iii) the deteriorative aspects, and (iv) the protective effects of the colonization.

\section{Biofilms and Lichens}

Scientific observations of a wide variety of natural habitats have established that the majority of microbes predominantly live in complex sessile communities known as biofilms (Bridier et al. 2017). Biofilms are highly structured assemblages of 
microbial cells attached to a surface and entwined in a matrix of self-produced extracellular polymeric substances (EPS) (López et al. 2010). The structured biofilm ecosystem enables microbial cells to resist stress and increase their tolerance to stressors, both at the level of individual microorganisms and collectively as a community (Flemming et al. 2016). The microorganisms within a biofilm can survive and thrive in harsh environments characterized by desiccation, low-nutrient concentrations, large temperature variations, and high exposure to wind, UV radiation, and physical damage (Jacob et al. 2018). Biofilms are present in natural, industrial, medical, household environments and, from the human point of view, they can be either beneficial or detrimental.

The characteristics of microbial cells forming biofilms are distinct from those of their planktonic counterparts; their higher resistance to antimicrobial agents and ultraviolet radiation (UV), the development of physical and social interactions, an enhanced rate of gene exchange, and the selection for phenotypic variants are traits related to the structural characteristics of the community (Hentzer et al. 2003; Flemming et al. 2016; Di Martino 2016; Bridier et al. 2017; Mittelmann 2018). Indeed, both the microbial development and the matrix lead to the growth of a cooperative consortium that offers a protective structure able to hinder diffusion and action of antimicrobials (Bridier et al. 2017).

The process of biofilm development is coordinated by molecular pathways while the spatial structure of the biofilms is dependent on the species as well as on the environmental conditions (Tolker-Nielsen 2015). Cell-to-cell biochemical signals influence each step in the process of biofilm formation and enhance the persistence of both individual species and the biofilm (Katharios-Lanwermeyer et al. 2014; Vega et al. 2014). Multispecies biofilm is a result of cell-cell and cell-environment interactions such as cooperation, competition or exploitation (Liu et al. 2016). The spatial organization of biofilms is driven by the specific interactions between species.

The first step in the development of biofilms is the formation of a conditioning layer on noncolonized surfaces (Fig. 1.1). The layer is formed by organic substances like polysaccharides and proteins which improve the attachment of initial colonizers. In the second step, microbial cells attach to these substances due to their size and net negative charge by nonspecific interactions, such as electrostatic, hydrophobic, and van der Waals forces (Mittelmann 2018). Hydrophobicity and electric charge of the conditioning substances are of importance in bacterial adhesion (Diao et al. 2014). The electrostatic forces are weak and reversible at this stage. At a later stage, cells firmly adhere to the surface and to each other, producing EPS that entrap cells and debris within a glue-like matrix (Fig. 1.1). EPS can increase the rate of coaggregation of cells (Mittelmann 2018). Polysaccharides are characteristic components of the EPS, but proteins, nucleic acids, lipids, and humic substances have also been identified, sometimes in substantial amount. As mentioned above, the matrix-a three-dimensional, gel-like, highly hydrated and locally charged (often anionic) material-is composed of EPS the proportion of which, in general, can vary between roughly $50 \%$ and $90 \%$ of the total organic matter. EPS play significant roles in the attachment of microorganisms to the mineral surfaces and in the protection of the microbial community from toxic compounds (Diao et al. 2014). At this stage, the 


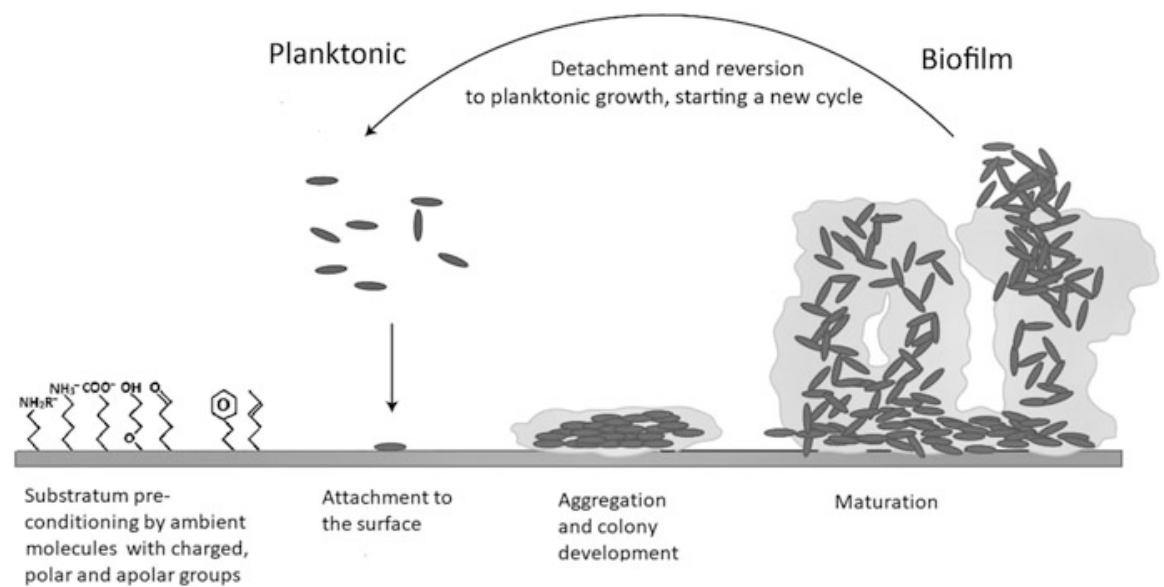

Fig. 1.1 Stages leading to microbial formation on a surface. Once cells attach to surfaces irreversibly, they replicate and grow forming microcolonies. The microbial cells secrete extracellular polymeric substances (EPS) and become encapsulated in a hydrogel layer, which forms a physical barrier between the community and the extracellular environment. The community forms a threedimensional structure and matures into a biofilm. Cells in an established biofilm are "glued" together by the EPS, which resist mechanical stresses and detachment of the community from the surface of the substratum. Some cells detach from regions of the biofilm and disperse to form biofilms in new environmental niches

biofilm environment is a rich layer of nutrients that can support rapid growth of the microorganisms within it. Biofilms are thus accumulations of microorganisms, EPS, multivalent cations, inorganic particles, biogenic materials, colloidal, and dissolved compounds. As the microcolonies grow, additional species, the so-called secondary colonizers, are recruited through coaggregation and nonspecific aggregation interactions, increasing the biofilm biomass and species complexity (KathariosLanwermeyer et al. 2014). This process allows species that cannot adhere to the noncolonized surfaces to become part of the biofilm (Gorbushina 2007). In the mature biofilm, complex diffusion channels transport nutrients, oxygen, and other necessary elements for cells, and carry away metabolic waste products. The last stage of biofilm lifestyle is the dispersal of cells from the biofilm colony, which enables it to spread and colonize new surfaces (Fig. 1.1).

Exposed heritage surfaces are mostly low-nutrient environments. The formation of biofilms is a survival mechanism adopted by microorganisms. Other survival mechanisms are nutritional versatility, cellular morphological changes, and formation of spores (Mittelmann 2018). Moreover, microbial cells can enter a viable but non-culturable state reducing their respiration rates and densities yet retaining their essential metabolic activities in response to nutrient deficiency (Mittelmann 2018). Associations of phototrophic and heterotrophic microorganisms often compose the biofilms that grow on heritage objects. Photosynthetic microorganisms sustain the development of heterotrophs through the production of EPS such as polysaccharides 
(Villa et al. 2015). The heterotrophs, in turn, can promote the growth of autotrophs by supplying key substances and other products.

A lichen is a mutualistic symbiotic association between green algae or cyanobacteria and fungi. The mutual life form has properties quite different from those of its component organisms growing separately. The fungal component of the lichen is called mycobiont, while the photosynthesizing organism is called photobiont. Photobionts are green algae and cyanobacteria. Most lichens are associated to green algae. The photobiont produces the nutrients needed by the entire lichen, while the mycobiont produces large numbers of secondary metabolites, the lichen acids, which play a role in the biogeochemical weathering of rocks and in soil formation. The nonreproductive tissue, or vegetative body part, is called thallus. Nearly all lichens have an outer cortex, which is a dense, protective layer of hyphae. Below it, there is the photosynthetic layer. Then, a layer of loose hyphae, the medulla, is present. Foliose lichens have a lower cortex with rhizines, which anchor them to the substratum, while crustose lichens attach to the substratum through the medulla. Lichens come in many colors (white, black, red, orange, brown, yellow, and green), shapes, and forms. Three major growth forms are recognized: crustose that is flattened and adheres tightly to the substratum; foliose with flat leaf-like lobes that lift from the surface; fruticose that has tiny, multiple leafless branches threedimensional growing.

The mycobiont produces the fruiting bodies, which are spore-producing structures. The most common sexual fruiting bodies are the apothecium and the perithecium. Apothecia typically are structures cup or disc-shaped, often with a distinct rim around the edge. The hymenium, the tissue containing the asci, forms the disc, the upper surface of the apothecium. Two basic types of apothecium are recognized in lichens, differing in their margins and underside (together named "the exciple"). In lecanorine apothecia, the thallus tissue extends up the outside of the apothecium to form the exciple and the rim. This margin generally retains the color of the thallus and normally contains algal cells. In lecideine apothecia, the exciple is part of the true apothecial tissue and does not contain algal cells. Discs that become very contorted and appear as line segments on the surface of the thallus are called lyrellae.

Perithecia are usually flask-shaped fruiting bodies enclosing the asci. At maturity, an apical opening, the ostiole, releases the ascospores. Perithecia are usually partially embedded in the thallus or in the substratum and are relatively small, rarely more than $1 \mathrm{~mm}$ in diameter and commonly much less.

\section{Factors Influencing Microbial Colonization}

Inorganic cultural heritage materials differ in surface texture, hardness, porosity, $\mathrm{pH}$, and chemical composition, characteristics that make them favorable or unfavorable to microbial colonization. 
The susceptibility of stones to hold organisms is called bioreceptivity, a term coined by Guillitte (1985). In other words, it is the aptitude of a stone to be vulnerable to organisms' colonization. Guillitte further defined this concept. The primary bioreceptivity indicates the potential of a healthy material to be colonized; the secondary bioreceptivity is the result of the deterioration caused by abiotic and biotic factors; finally, the tertiary bioreceptivity is prompted by nutrients contained in the substratum (e.g. dead biomass, dust particles, animal feces, water repellents and consolidants, biocides, etc.).

There are several reports in the literature on studies conducted either in situ or under laboratory conditions on the assessment of bioreceptivity. Highly porous materials are more susceptible to microbial colonization because of their capacity to absorb more water and retain it in for longer periods of time. Surface roughness affects the trapping of moisture and concentrates it in micro-fissures where growth is usually more abundant. It also enables the accumulation of particles - soot, organic and inorganic debris, pollens, spores, and salts (Jacob et al. 2018). In addition, rougher surfaces can be a preferential site for colonization because they provide shelter from wind, desiccation, and excessive solar radiation (Miller et al. 2012b; Jacob et al. 2018). Evidence of the importance of these physical characteristics is given by the resistance to microbial colonization of smooth and impermeable surfaces of glazed ceramics unless fissures are present.

Studies on primary and secondary bioreceptivity of granites showed that the growth of phototrophic biofilms is strongly enhanced by high open porosity, capillary water content, surface roughness, and abrasion $\mathrm{pH}$ rather than by differences in the chemical and mineralogical composition of the rocks (Prieto and Silva 2005; Vázquez-Nion et al. 2018a, b). Abrasion $\mathrm{pH}$, measured after grinding the rock in distilled water, relates to the number of basic cations released by the rock when in contact with aqueous solutions. Open porosity is correlated with void spaces in the rock; thus, it refers to the capacity of rock to absorb water. Capillary water absorption, providing information about the pattern of the pore network, is connected to the time the rocks remain wet. Despite the above-mentioned stone properties are assumed as the most important to determine bioreceptivity of natural and artificial stones, some studies showed that the chemical composition and petrography appear to be crucial factors as well (Miller et al. 2012b). A study (Miller et al. 2006) on limestone, granite, and marble samples artificially inoculated with two photosynthetic microorganisms (the cyanobacterium Gloeocapsa alpina and the green microalga Stichococcus bacillaris) showed that limestone and marble, which had the highest $(>17 \%)$ and the lowest $(\leq 1 \%)$ porosity, respectively, supported the greatest microorganisms' colonization while granite showed just a limited growth. The result apparently depends mainly on the chemical composition rather than on the physical characteristics of the stones. Similarly, the importance of stone chemical composition emerged from a laboratory experiment (Olsson-Francis et al. 2012) that showed basalts have higher rates of cyanobacterial growth and dissolution than rhyolitic rocks. According to the authors, the difference is due to a higher content of quartz, which has a low rate of weathering, and to lower concentrations of bio-essential elements, such as $\mathrm{Ca}, \mathrm{Fe}$, and $\mathrm{Mg}$. A research on the prevention of 
biological colonization in the archaeological area of Fiesole (Italy) (Pinna et al. 2012, 2018) assessed the secondary bioreceptivity of some stones (sandstone, marble, plaster) where crustose lichens were previously removed. The 8-year-long study showed that the recolonization of the three substrata after the cleaning depended mainly on their bioreceptivity and on climatic conditions. Marble showed a high bioreceptivity as, at the end of the monitoring, fungi and lichens covered the surfaces. On the contrary, sandstone and plaster showed very low bioreceptivity. Unlike marble, the pioneer species on sandstone were lichens that started developing more than 4 years after cleaning. At the end of the monitoring, the lichens grew extensively on sandstone surfaces, but did not cover them completely. Although the position near the ground of the test area of the original Roman plaster would be expected to be favorable to biological growth, it was the least bioreceptive substratum as, at the end of the monitoring, almost no biological colonization was detected on the surfaces. It showed a low water absorption due to the presence of cocciopesto, ${ }^{1}$ of a natural wax, and of an outer thin whitish calcite layer. These substances likely made it non-hygroscopic and prevented microbes' growth. As the environmental conditions of the tested areas did not differ and the porosity was quite low on all the stones, arguably the different bioreceptivity can relate to their chemical composition, $\mathrm{pH}$, shape and orientation of pores, pore size distribution and surface texture.

Different types of stone show different bioreceptivities toward lichen colonization as it has been shown in a study of gravestones in Jewish urban cemeteries in north-eastern Italy (Caneva and Bartoli 2017). Trachyte mainly hosted the growth of the lichen Protoparmeliopsis muralis which covered horizontal surfaces. Verona stone, marble, and Istrian stone were less colonized while Nanto stone, a soft yellowbrown limestone, was the material mostly affected by lichen colonization, and suffered the highest degree of deterioration.

Substratum pH influences biological colonization because some organisms prefer specific values or tolerate a narrow $\mathrm{pH}$ range. Extreme $\mathrm{pH}$ values are not favorable because of the damaging effect of $\mathrm{H}^{+}$or $\mathrm{OH}^{-}$ions. Although most microorganisms tend to live in $\mathrm{pH}$ neutral conditions, some may colonize cement over a wide pH range (Allsopp et al. 2004; Prieto and Silva 2005; Miller et al. 2012b). Many fungi prefer slightly acidic substrata (e.g. granites, some sandstones), while alkaline conditions (e.g. limestone, marble, lime mortars) may favor cyanobacteria (Caneva and Ceschin 2008). As a fresh concrete has a pH of 12-13, it permits microbial growth when $\mathrm{pH}$ is lowered by reaction with atmospheric carbon dioxide (carbonation) (Allsopp et al. 2004). The alkalinity of concrete is crucial to decrease the rate of biodeterioration by inhibiting the microbial activity (Noeiaghaei

\footnotetext{
${ }^{1}$ Cocciopesto is a decorative plaster dating back to Roman times. The Romans utilized it to implement durable floors or as a base to lay their intricate stone mosaics. Made with crushed soft fired brick and lime putty, cocciopesto is a highly resistant finish able to withstand wet or humid environments.
} 
et al. 2017). Thus, the degree of carbonation and $\mathrm{pH}$ values play a key role in the receptivity of concrete and mortars to microbial colonization.

Differences in abundance of colonization on stones can be due to tertiary bioreceptivity related to nutrients contained on the surfaces or in the stones (Salvadori and Charola 2011). They can derive from existing biological growth on the surface, bird droppings, organic compounds used in restoration practice, pollutants. Air and rain carry nutrients in the form of dust and soil particles. Soil fertilization leads to an accumulation of nitrates and phosphates (eutrophication) that are contained in bird droppings too. Some lichens (nitrophilic species) have been adapted to high nitrogen levels. Generally, they have an orange thallus, easily observed on roofs, architectural moldings, horizontal surfaces of statues where the eutrophication derived from bird droppings and/or fertilizers transported by air and rain.

Along with substrata' bioreceptivity and capacity to retain water, the environment surrounding the monument and the monument itself act as limiting factors of biological growth. Local microclimate, macroclimate, wind-driven rain, pollution, geographical location, architectural design and details of monuments or sculptures are remarkable factors influencing organisms' colonization (Tonon et al. 2019). Tropical climate conditions in Far East, for example, enhance the establishment and widespread colonization of microflora on cultural heritage objects due to high water availability during monsoon season (Zhang et al. 2019).

The importance of wind-driven rain to the abundance of microbial colonization of surfaces emerged from a five-year-long study in the archaeological site of Pompeii, Italy (Traversetti et al. 2018). The extent of microbial growth was much broader on northern and western exposures respect to south-exposed walls. Comparison of climatic parameters, data of the dominant winds and microorganisms' occurrence (cyanobacteria, algae, and lichens) showed that wind-driven rain along with lower temperatures and poor ventilation of northern exposure strongly affected stones' wetness and played a key role in the promotion of microbial development. A similar study documented that the moisture contents in the walls of a brick tower was higher near the edges of the walls than at the center just for wind-driven precipitation, inducing fungal mold colonization especially at this position (Abuku et al. 2009). In these studies, the orientation of the object towards the light was an aspect affecting microbial colonization as well. In wet climates and northern latitudes, north-exposed surfaces get less direct sunlight. Therefore, once wet, they remain damp for much longer than other stones. This slow-drying condition is much more favorable to biological colonization than the hostile condition of rapid wetting and drying cycles experienced on the south faces (Adamson et al. 2013). Similarly, in a different climate and latitude (south of Brazil) painted surfaces showed higher fungal colonization on south-facing sides that received less solar radiation than north-facing ones. If the surface temperature fell below dew point at night, they remained moist for longer periods of time after wetting (Shirakawa et al. 2010).

Temperature and relative humidity are key parameters influencing the development of fungi (Jain et al. 2009). Most of them may be grouped into three categories on a thermal basis. Psychrophiles thrive at temperatures between $0{ }^{\circ} \mathrm{C}$ and $5{ }^{\circ} \mathrm{C}$, 
mesophiles between $20{ }^{\circ} \mathrm{C}$ and $45{ }^{\circ} \mathrm{C}$, while thermophiles at or above $55{ }^{\circ} \mathrm{C}$. Members of the Mucoraceae and Deuteromycetes grow on substrata at relative humidity of 90-100\% and not below, while members of the Aspergillus glaucus group grow at relative humidity as low as $65 \%$ (Jain et al. 2009). Temperature may also affect the stone water content. The influence of surface temperature showed a significant positive correlation with green algae biofilms in a survey of four sandstone heritage structures in central Belfast (Ireland) exposed for around 100 years (Cutler et al. 2013). Areas with lower temperatures were, on average, greener than warmer areas. As reported by the authors, it is possible to model algal greening of sandstones from the scaled-down outputs of regional climate models as it mostly relates to climate and atmospheric particulates.

In hot climates sunny surfaces are more hostile and variable than those shaded, thus the production of extra cellular polymeric substances tends to be higher to protect the cells from the adverse conditions (Scheerer 2008). Moreover, microbial biomass and species diversity are usually much higher in shaded areas (Ramírez et al. 2010).

\section{Biodeterioration Processes Caused by Biofilms and Lichens}

Microorganisms that play a potential role in biodeteriorative processes of inorganic materials are autotrophic and heterotrophic bacteria, fungi, algae and lichens.

Microbial biofilms interact with inorganic materials in several ways: physical deterioration, where materials structure is affected by microbial growth (e.g. physical or mechanical breaking); aesthetic deterioration due to fouling; chemical deterioration, mineral and metal transformations due to excretion of metabolites or other substances such as acids that adversely affect the structural properties of the material (e.g. increasing of porosity, weakening of the mineral matrix, dissolution of minerals and formation of biominerals, biocorrosion of metals and alloys).

The physical and chemical weathering of rocks by lichens-mainly epilithic and endolithic crustose species - encompasses the following mechanisms: hyphae growth in intergranular voids and mineral cleavage planes; expansion and contraction of the thallus by wetting and drying, and freeze-thaw cycles; incorporation of mineral fragments into the thallus; swelling and deteriorative action of organic and inorganic acids; dissolution/etching of mineral grains and precipitation of amorphous and crystalline compounds.

In addition, the dissolution of respiratory $\mathrm{CO}_{2}$ contained in water held by biofilms and lichen thalli can lower the $\mathrm{pH}$ at the substratum-thallus interface, accelerating the chemical weathering of the rocks (Di Martino 2016).

Effective physical weathering requires chemical weathering since the growth in the stone of biofilms and lichens is facilitated by the dissolution of minerals along grain boundaries, cleavages, and cracks. The overall effect increases porosity and 
Fig. 1.2 Statue in the park of Nympheburg, Munich, Germany. The statue's surface is almost completely covered by biofilms and lichens that strongly compromise its legibility

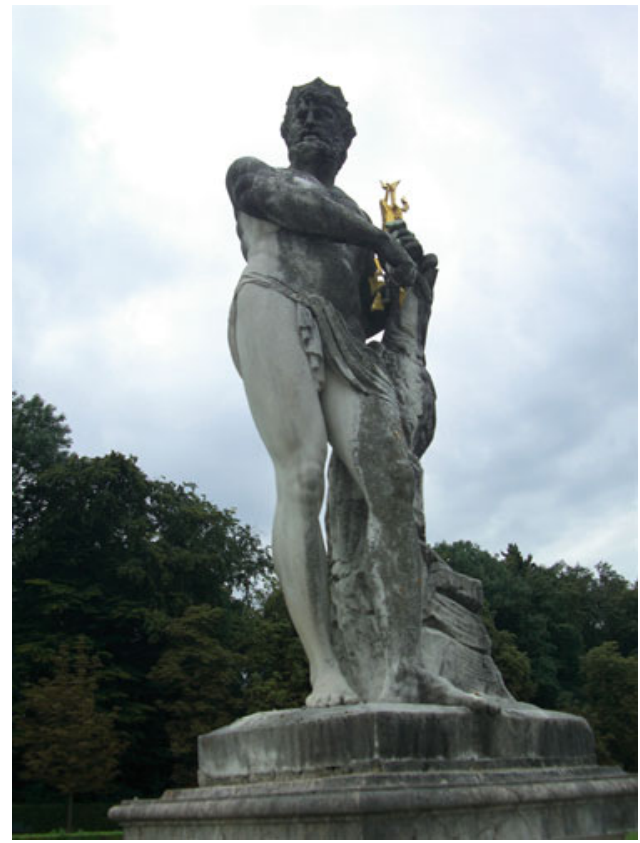

permeability. Since these weathering processes interact and enhance each other action, it is impossible to separately quantify their role (Bjelland and Thorseth 2002; de Los Rios et al. 2002).

As for natural and artificial stones, the aesthetic aspects assume an important role because biofilms' and lichens' development is an impediment to the site's presentation to the audience when it compromises the legibility of a monument (Ashbee 2010) (Fig. 1.2).

\subsection{Stone}

The so-called biomineralization or biologically induced mineralization is the process by which biological activity induces the precipitation and accumulation of minerals. It is the result of the metabolism of the organisms and is present in all five kingdoms of life. Minerals produced by biofilms and lichens include iron hydroxides, magnetite, manganese oxides, clays, amorphous silica, carbonates, phosphates, oxalates (Konhauser 2007; Dupraz et al. 2009; Miller et al. 2012a; Urzì et al. 2014). Biomineralization produced by fungi occurs when they modify the local microenvironment creating conditions that favor extracellular precipitation of mineral phases (Fomina et al. 2010; Gadd et al. 2014).

Stone-inhabiting microorganisms may grow on the surface (epiliths) or some millimeters or even centimeters in the substratum (endoliths) (Gadd et al. 2014). The 
endolithic colonization is an adaptive strategy developed by cyanobacteria, algae, fungi, and lichens. The use of the substratum as a shield against external stress proves to be a decisive evolutionary selection advantage (Pohl and Scheider 2002). The endolithic mode of life includes different ecological niches: chasmoendoliths and cryptoendoliths occupy preexisting fissures and structural cavities in the rocks, whereas euendoliths grow in soluble carbonatic and phosphatic substrata dissolving the stone immediately below the surface. The first form of growth leads to a co-responsibility in the detachment of scales of material due to the pressure exerted by increasing biomass. This process can occur repeatedly, involving areas increasingly in depth (Pinna and Salvadori 2008). The light that reaches the bulk of the stones limits the growth of phototrophic microorganisms. The presence of water in micropores, especially those with translucent walls, may enhance light penetration, increasing the light available for photosynthesis in the cryptoendolithic habitats (Cámara et al. 2014). Euendoliths form microcavities of varying morphologies according to the species.

Stones subjected to extreme sun irradiation in hyper-arid Atacama Desert (Chile) are colonized by endolithic algae and cyanobacteria. In order to endure the harsh environment, they synthesize carotenoids and scytonemin, respectively. The production of these pigments is interpreted as an adaptation strategy against high doses of solar irradiation as they are passive UV-screening pigments (Vítek et al. 2016).

Cyanobacteria and microalgae are often the first colonizers of stone surfaces where they develop phototrophic biofilms. Algae form colored (green, gray, black, brown, and orange) powdery patinas, and gelatinous layers. They usually dominate surfaces in wet and rainy areas. Cyanobacteria typically form dark brown and black patinas but also pink discolorations. Besides the aesthetic disturbance caused by the colored patinas, algae and cyanobacteria cause water retention and damage due to freeze-thaw cycles. Areas colonized by dark biofilms formed by cyanobacteria may absorb more sunlight. Temperature changes increase mechanical stress by expansion and contraction of the biofilms (Scheerer et al. 2009).

The main groups of fungi isolated from stone monuments are Hyphomycetes and black meristematic fungi (Salvadori and Casanova 2016). Hyphomycetes, commonly known as mold, are a class of asexual or imperfect fungi. They lack fruiting bodies, the sexual structures used to classify other fungi. The production of conidia (spores) occurs by fragmentation of vegetative hyphae or from specialized hyphae called conidiophores. Since the attachment of airborne spores to surfaces is the first step of fungal colonization, the species diversity of fungi present on stones is similar to the diversity of common airborne spores (Sterflinger and Piñar 2013). Many Hyphomycetes, notably Aspergillus, Fusarium, and Penicillium genera, produce toxic metabolites (mycotoxins). Several Hyphomycetes growing on stone heritage objects are dematiaceous. The term refers to the characteristic dark appearance of these fungi that form dark gray, brown or black colonies. Fungi excrete organic acids (oxalic, citric, acetic, formic, gluconic, glyoxylic, fumaric, malic, succinic, and pyruvic) that can act as chelators. Particularly, oxalic acid has a high capacity of degrading minerals for its complexing and acid properties. Its importance relates to the ability of the oxalate anion to complex and/or precipitate metals as secondary 
Fig. 1.3 Early development of black meristematic fungi on the wealthy surface of a marble model sample exposed outdoor. Stereomicroscope, $50 \times$

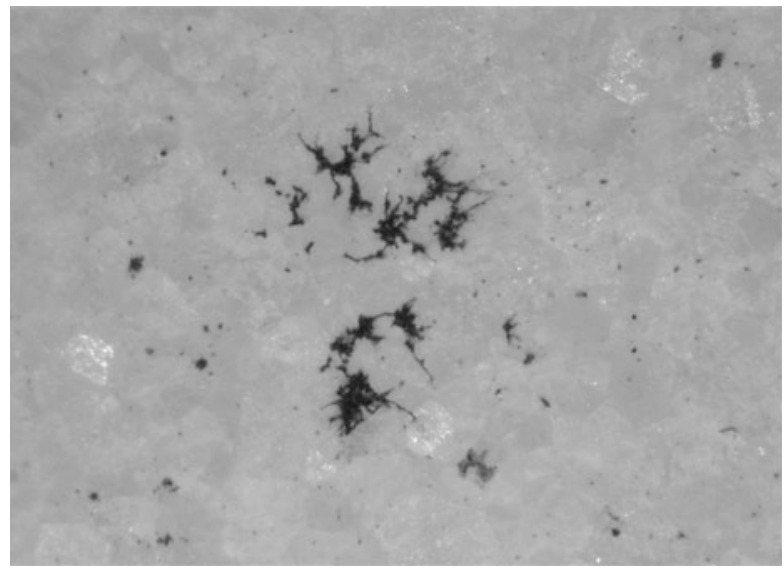

biominerals. The reaction results both in mineral dissolution and in mineral formation (Gadd et al. 2014). Calcium oxalate precipitation has an important influence on biogeochemical processes in soils, acting as a calcium reservoir (Gadd et al. 2014). The precipitation of secondary minerals (carbonates and oxalates) on and within stones, and the mineral dissolution connected to fungal growth lead to the formation of crusts on the surface and around the hyphae that can progressively cement fissures and cracks (Fomina et al. 2010).

An investigation into a thin dark rock coating at the Ngaut Ngaut heritage complex in South Australia showed that it contained a mixture of calcite, quartz, gypsum, and weddellite (Roberts et al. 2015). The dark coating covered petroglyphs engraved in the rock shelter and dated back around 3000 years B.C. According to the authors, the weddellite was likely formed from the reaction of calcite with oxalic acid excreted by surface microflora.

Metal mobilization can also be achieved by chelation ability of siderophores. When living in environments of reduced iron content, fungi produce iron(III)binding ligands, commonly of a hydroxamate nature, termed siderophores (Salvadori and Casanova 2016).

Black meristematic fungi belong to the genera Hortaea, Sarcinomyces, Coniosporium, Capnobotryella, Exophiala, Knufia, and Trimmatostroma (Sterflinger and Piñar 2013). Their cells have thick pigmented walls. They form slowly expanding, cauliflower-like colonies that grow by isodiametric enlargement of the cells (Sterflinger 2010) (Fig. 1.3). In addition to the meristematic growth, many of the black fungi can exhibit a yeast-like growth (De Leo et al. 2003). They abandoned the hyphal phase adopting the microcolonial or yeast phase characterized by an extremely slow growth, in response to the lack of organic nutrients and to stresses of outdoor substrata. The microcolonial phase enhances the survival and persistence of these fungi in the biofilms. They produce various pigments including carotenoids, mycosporines, and melanins that protect them from UV irradiation. Moreover, melanin provides them with extra-mechanical strength making hyphae able to grow better in fissures. Microcolonial fungi, as well as cyanobacteria, algae 

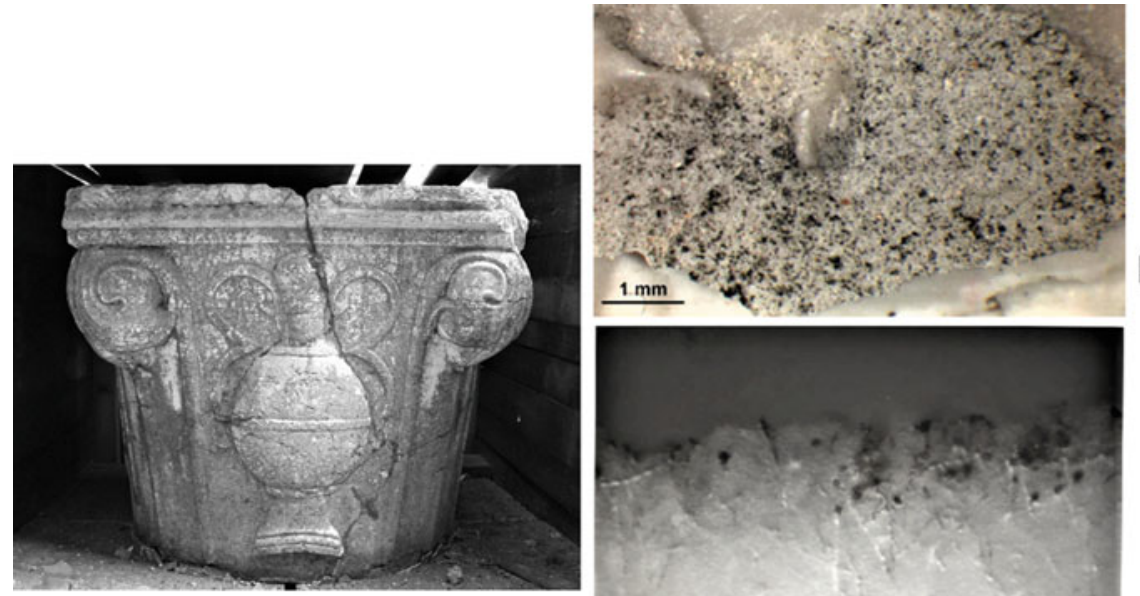

B

A

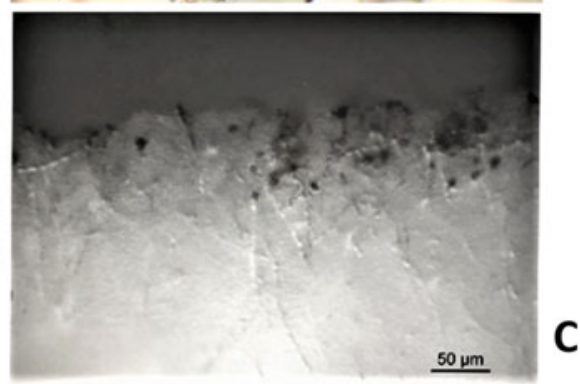

Fig. 1.4 Marble well-curb (Montefiore Conca, Italy) colonized by biofilms (a). Peculiar pattern of stone weathering on a sample. Biofilms form little black spot on the surface. Stereomicroscope (b). Polished cross section of the sample showing black fungi on the surface and hyaline hyphae in the bulk of the stone (c)

and lichens, are poikilohydric microorganisms, which means that they are metabolically active or dormant depending on water availability. They can thrive under extreme conditions including irradiation, temperature, salinity, $\mathrm{pH}$, and moisture. They are stress-tolerant colonizers involved in biodeterioration (de los Rios et al. 2009; Sterflinger 2010; Marvasi et al. 2012; Onofri et al. 2014; Salvadori and Casanova 2016). On marbles, they grow in the inter-crystalline spaces (Fig. 1.4) contributing to the loosening and detachment of crystals and forming biopitting. However, the scarcity of nutrients and the very slow growth limit their contribution to weathering (Hoffland et al. 2004). Biopitting is an alteration caused by euendolithic microorganisms that form little blind holes close together (Golubic et al. 2005) (Fig. 1.5). The stone frequently associated with this kind of deterioration is marble (53\%), followed by carbonate rocks (44\%), granite, and concrete (3\%). Bio pitting is caused mostly by cyanobacteria along with fungi (11\%), lichens (10\%), and algae (5\%) (Lombardozzi et al. 2012).

Wall paintings may have a "double nature," inorganic and organic. In the history, they have been made using several techniques. The best known is fresco (from the Italian word affresco that derives from the adjective fresco "fresh") that uses water-soluble pigments applied on wet plaster or lime mortar. The pigments are absorbed by the wet plaster. When drying, the plaster reacts with the air in a process called carbonation in which calcium hydroxide reacts with carbon dioxide and forms insoluble calcium carbonate; this reaction fixes the pigment particles in the plaster. The technique called a secco fresco uses instead dry plaster (secco means "dry" in 

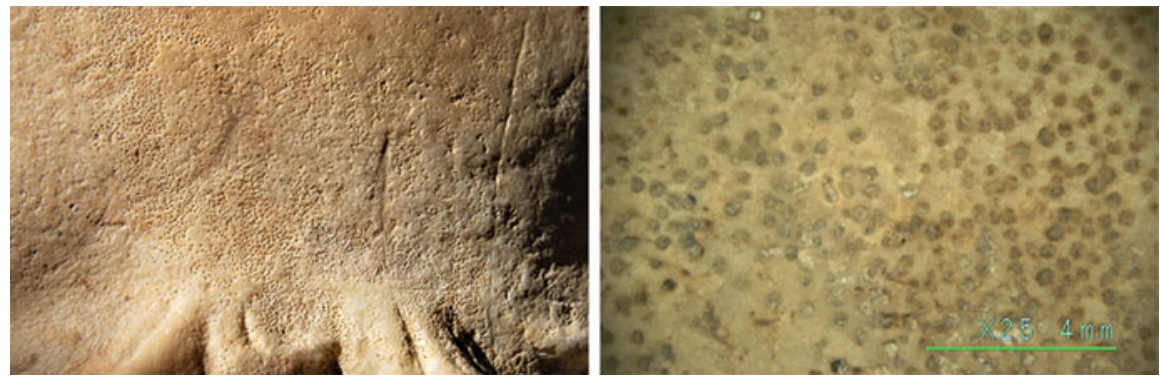

Fig. 1.5 Biopitting on a stone statue, Uffizi Gallery (Firenze, Italy). Close-up of a detail of the surface (right). The circular micro-holes were likely produced by endolithic lichens that grew when the statue was located outdoors. The fruiting bodies were present inside the holes. After the lichens died, they left just the empty holes

Italian). An organic binding medium, like egg, glue, or oil, is needed to fix the pigment into the plaster. In Classical Greco-Roman times, the encaustic painting technique was in use. Pigments were ground in a molten beeswax binder (or resin binder) and applied to the surface while hot. Today, murals are mostly painted in oils, tempera, or acrylic colors. Microbial colonies may deteriorate either the inorganic component or the organic one causing efflorescence, expansion cracking, peeling and spalling of outer layers, color changes, and stains. Oxalates may be produced from the calcite or from metal-containing pigments of the painted layers (Gadd et al. 2014; Unković et al. 2017).

The deteriorative potential of fungi isolated from wall paintings was evaluated by in vitro studies to assess the risk of deterioration and formulate appropriate conservation treatments. Some biodegradative properties-calcite dissolution, casein hydrolysis, pigment secretion, acid and alkali production-were tested using specific agar culture media (Pangallo et al. 2012; Unković et al. 2018). Many species of the genera Aspergillus and Penicillium demonstrated the ability to dissolve calcite as they produced and secreted acids; oxalic acid was the main cause of deterioration in most instances (Ortega-Morales et al. 2016). Species of the genus Cladosporium hydrolyzed casein showing high proteolytic activity (Unković et al. 2018). They are thought as the primary degraders of protein components of painted layers of wall paintings. Applying the mentioned method, the authors detected also species showing no deterioration capabilities.

Pink patinas and rosy discolorations occurring on stones and wall paintings may be caused by bacteria and algae. In the crypt of the Original Sin (Matera, Italy), the pink color resulted from the production of a ruberin-type carotenoid pigment produced by actinobacteria (Nugari et al. 2009). Similarly, carotenoids caused pink and yellow discolorations on wall paintings of St. Botolph's Church (Hardham, UK) (Kyi 2006). According to the authors, the pigments provide microorganisms with a protective mechanism against damage caused by photooxidation reactions. Rosy-powdered areas on the frescoes of St. Brizio Chapel (Orvieto Cathedral, Italy) contained instead phycoerythrin, a pigment produced by capsulated coccoid 
cyanobacteria that grew even in the dark conditions of the chapel being able to use the organic compounds present on the fresco surface (Cappitelli et al. 2009). An analogous alteration on wall paintings of two churches in Georgia (Gittins et al. 2002) was due to the bacterium Micrococcus roseus while rosy discoloration on walls of Terme del Foro (Pompeii, Italy) were associated to the development of the bacterium Arthrobacter agilis which produced the pigment bacterioruberin (Tescari et al. 2018). Green algae belonging to the genus Trentepohlia formed red powdery spots on a medieval wall painting in Italy (Zucconi et al. 2012).

Subterranean environments like caves and catacombs are ecosystems characterized by unique microhabitats and a very delicate equilibrium of microbial communities living on surfaces and rock paintings (Urzì et al. 2018). The relative humidity is in most cases high (around 90\%), air circulation is very low, and the temperature is almost constant through the year (Urzi et al. 2018). The conservation of these sites is challenging; changes of microclimatic parameters (light regime, release of $\mathrm{CO}_{2}$ by visitors, modification of temperature and relative humidity) irreversibly change the whole microclimate resulting in biodeterioration of surfaces and rock paintings (Urzì et al. 2018). The microclimate of the Lascaux cave (France) was strongly affected by visitors (up to 1800 per day) and by the artificial lights installed to allow cave's view. Consequently, a green biofilm developed on the worldwide famous prehistoric drawings. Called "le maladie verte," it was formed by green algae belonging to Chlorophyta (Bastian et al. 2010). Then the paintings suffered from a fungal invasion by Fusarium solani which formed long white mycelia, and by dematiaceous fungi which produced black stains on the ceiling and passage banks (Bastian et al. 2010). These problems, which generated worldwide interest because the prehistoric drawings represent a priceless cultural heritage for all humankind, led to the closure of the cave in 1963. A similar case was that of the wall paintings of Takamatsuzuka Tumulus (Japan) discovered in 1972 (Miura 2006). The temperature of the tomb was quite stable until 1980, when it began to rise following the outdoor temperature. By 2000, concurrently with the opening to visitors, the temperature reached nearly $20{ }^{\circ} \mathrm{C}$ creating an ideal microclimate for fungi that widely colonized the wall paintings.

Several brown spots were spread on the wall paintings of the tomb of King Tutankhamun (Valley of the Kings, Luxor, Egypt) when it was discovered in 1922 (Szczepanowska and Cavaliere 2004). GC/MS analysis of the spots indicated that they contained $16 \%$ (by weight) of malic acid, suggesting microbial involvement in their formation (Vasanthakumar et al. 2013). Although located in a desert, over the centuries periodic floods occurred allowing moisture to enter the tomb chambers. The perspiration and breathe of visitors were a further source of moisture. According to a report by the Getty Conservation Institute (www.getty.edu/conservation), six people breathing in the tomb chamber for an hour raised the RH level by $3 \%$.

The paleolithic cave of Altamira in Spain was close to the public in 2002 after photosynthetic bacteria and fungi deteriorated the prehistoric paintings (Jurado et al. 2014).

In subterranean environments phototrophic biofilms composed primarily by cyanobacteria associated with heterotrophic bacteria and microalgae are a relevant 
cause of damage. The extent to which phototrophic microorganisms colonize the substrata highly depends on light intensity (Urzì et al. 2018). A progressive deepening of their growth in the substrata leads to the mobilization of elements and to higher water retention by polysaccharide sheaths. Mineral crystals were observed on the cells of some cyanobacteria (Scytonema julianum and Loriella sp.) and of heterotrophic bacteria of the genus Streptomyces isolated from caves' walls (Albertano et al. 2005). As reported by the authors, Streptomyces, associated to $S$. julianum, promote the precipitation of calcium carbonate on the polysaccharide sheath of cyanobacteria in the form of calcite crystals. A white crust formation is generally associated to the deposition of these crystals and it results in a stromatolitic layer on the stone surface. Calcium carbonate dissolution and precipitation are the main processes in the biotransformation of calcareous substrata in caves (Albertano et al. 2005). Similar $\mathrm{CaCO}_{3}$ crystals precipitation induced by Actinobacteria, Firmicutes, and Proteobacteria that grew on surfaces of Roman catacombs showed instead a different morphology being in the form of a white fluffy (Urzì et al. 2014). Actinobacteria produced extracellular pigments that caused color change of the wall paintings located in the Snu-Sert-Ankh tomb, Egypt (Elhagrassy 2018). Similarly, the development of chemoorganotrophic bacteria harmfully affected the painted surfaces of Hal Saflieni Hypogeum (Paola, Malta) where they extensively formed white alterations on ochre-decorated surfaces dated back to 3300-3000 B.C. (Zammit et al. 2008).

Biodeteriorative effects of lichens on stone cultural heritage objects are well documented. However, they varied considerably from species to species. The mechanisms involved in the weathering have been mentioned above. Lichens produce hundreds of carbon-based secondary substances (so-called lichen substances), most of which are unique to the lichen symbiosis. Depending on their chemical structure, they can act as complexing agents. One of the organic acids produced by lichens is oxalic acid, a strong complexing agent, as it has been discussed. It forms chelating bonds producing calcium, magnesium, manganese, and copper oxalate crystals at the rock-epilithic lichen interface, in the thalli, on their surface, and in the bulk of the stones down to the depth reached by fungal hyphae (Edwards et al. 2003; Skinner and Jahren 2003; Konhauser 2007; Dupraz et al. 2009; Viles 2012; Salvadori and Casanova 2016). Oxalates have been implicated in $\mathrm{Fe}, \mathrm{Si}$, $\mathrm{Mg}, \mathrm{Ca}, \mathrm{K}$, and $\mathrm{Al}$ mobilization from sandstone, basalt, granite, limestone, and silicates (Gadd et al. 2014; González-Gómez et al. 2018). Calcium oxalate occurs in two crystalline forms - the dihydrate (weddellite $\mathrm{CaC}_{2} \mathrm{O}_{4} \cdot 2 \mathrm{H}_{2} \mathrm{O}$ ) and the more stable monohydrate (whewellite, $\mathrm{CaC}_{2} \mathrm{O}_{4} \cdot \mathrm{H}_{2} \mathrm{O}$ ).

Dirina massiliensis $\mathrm{f}$. sorediata is one of the most deteriorating lichens, harmful to stones and wall paintings. Hyphae may develop into calcite up to $20 \mathrm{~mm}$ and calcium oxalate is present within the stone (Salvadori and Casanova 2016). Its vegetative reproduction allows a fast colonization of artworks' surfaces in a few years (Salvadori and Casanova 2016). In a medieval cave exposed to external environmental conditions this lichen grew on wall paintings and its gray-green powdery thalli formed a compact and continuous crust that included materials derived from the paintings. Old thalli appeared inflated at the center creating 
blister-like structures and causing the detachment of painting layers (Nugari et al. 2009). The decay and detachment of the center part of the thallus occur in other lichen species and open the underlying area to further weathering, resulting in cratered mounts on the rock surface (Mottershead and Lucas 2000).

Endolithic lichens develop their biomass in the bulk of the stones, with colonization patterns varying among species. A study on the anatomy of five calcicolous endolithic lichens showed that the photobiont layer is located at the same depth, $100-180 \mu \mathrm{m}$, from the surface, but the arrangement and depth of diffusion of hyphae into the stones vary considerably among species (Pinna et al. 1998). A different, atypical pattern of growth is that of Pyrenodesmia erodens, an euendolithic lichen able to dissolve limestones to a depth of several millimeters. It forms, with aging, confluent, moniliform depressions (Tretiach et al. 2003). Its thallus is composed by clusters of green algae surrounded by inflated, appressed hyphae. The clusters are arranged in bores formed by dissolution of the rock. This lichen has been found in dry sites of the Mediterranean region and of the southern Alps on exposed, subvertical faces of limestone and dolomite rocks (Tretiach et al. 2003). Its occurrence has been reported on the calcareous rocks of monumental remains in Pasargadae, UNESCO world heritage site in Iran (Sohrabi et al. 2017). The study focused on the lichen colonization and deterioration patterns in the semi-arid conditions of the area. Besides the effects of Pyrenodesmia erodens, other epilithic and endolitihic lichens showed damaging action such as pitting and granular disaggregation. Therefore, lichen communities are a potential threat for the conservation of the archaeological site. Moreover, lichen colonization and deterioration patterns do not appear peculiar respect to what has been previously described by the literature about colonized limestones in temperate and semi-arid areas around the Mediterranean basin.

The chemical deterioration of silicate and carbonate rocks by endolithic lichens relates to the secretion of siderophore-like compounds and of carbonic anhydrase (Favero-Longo et al. 2011). This enzyme increases the speed of the reaction $\mathrm{CO}_{2}+\mathrm{H}_{2} \mathrm{O} \leftrightarrow \mathrm{HCO}_{3}^{-}+\mathrm{H}^{+}$, thus it accelerates the dissolution of calcium carbonate. However, the study of calcium carbonate deterioration by endolithic lichens needs further experimental evidence and it is an interesting goal for further research. The present results, yet relevant, enlighten the complexity of the phenomenon.

Endolithic lichens form biopitting on limestones, with pits' diameter ranging from 0.2 to $1-2 \mathrm{~mm}$ depending on the size of fruiting bodies (Salvadori and Casanova 2016) (Fig. 1.5). When lichen death occurs, the empty pits are progressively enlarged by water (rainfall, water runoff, water accumulation). Then they can coalesce forming larger interconnected depressions. Unlike epilithic species, endolithic ones are not characterized by the production of calcium oxalates.

A one-year long laboratory experiment on lichen-rock interactions was conducted using mycobionts and photobionts of the endolithic lichens Bagliettoa baldensis and B. marmorea (Favero-Longo et al. 2009). They were isolated and then inoculated on marble and limestone samples. The same species growing on limestone outcrops and abandoned marble quarries showed penetration pathways similar to those reproduced in vitro. The study highlighted that erosion processes caused by 
lichen development increased the availability of hyphae passageways only after long-term colonization. The differences in hyphae growth depended on the mineral composition and structure of the lithotypes.

Different climates affect the endolithic growth of lichens (Pohl and Scheider 2002). In the humid Northern Alps (Austrian glacier), the bulk of the calcareous rock, just under the surface, showed three layers. At a depth of $0-150 \mu \mathrm{m}$, the substratum is mostly intact, just partly interlocked with the lichen litho cortex. At 150-300 $\mu \mathrm{m}$, photobionts (green algae or cyanobacteria) are capable of actively dissolving the substratum, thus creating habitable cavities. Then several $\mathrm{mm}$ in depth, there is the mycobiont with hyphae actively solubilizing the substratum and often forming dense networks. Most biomass of endoliths on carbonate rocks in the arid Mediterranean-Maritime Alps (Provence, France) was instead confined just under the surface. The average colonization intensity and growth depth are markedly deeper in the more humid substratum of the Austrian Alps.

\subsection{Stained-Glass Windows}

Glass is a non-crystalline, amorphous inorganic solid. The most familiar types of glass are prepared by melting and rapidly cooling quartz sand and other ingredients sodium carbonate $\left(\mathrm{Na}_{2} \mathrm{CO}_{3}\right.$, "soda"), lime (calcium oxide- $\mathrm{CaO}$ ), magnesium oxide $(\mathrm{MgO})$, and aluminum oxide $\left(\mathrm{Al}_{2} \mathrm{O}_{3}\right)$. The resulting glass contains about $70-74 \%$ silica by weight and is called a soda-lime glass (Na-rich glass) which accounts for about $90 \%$ of manufactured glass. To color the glass, powdered metals are added to the mixture while the glass is still molten. The medieval stained-glass windows that decorate many European churches were made using, besides sand, a different ingredient, the so-called potash that is wood ash $\left(\mathrm{K}_{2} \mathrm{O}, \mathrm{K}\right.$-rich glass). These glasses are more easily decayed than Na-rich ones.

Biofilms' growth on glass is correlated to tertiary bioreceptivity. Neither the inorganic composition nor the physical features of glass favor microbial colonization, but the organic residues of various origins, as dust deposits, dead microbial material, and bird droppings, can be a source of nutrients. The deteriorative action of microorganisms on glass is a modest, slow, yet continuous process that can accelerate its weathering. Research focused mainly on medieval stained-glass windows of European churches where corrosion, patinas, pitting, cracks, and mineral crusts occur. Microorganisms may contribute to all these decay forms (Carmona et al. 2006; Marvasi et al. 2009; Piñar et al. 2013). Analyses revealed complex bacterial communities consisting of members of the phyla Proteobacteria, Bacteroidetes, Firmicutes and Actinobacteria (Piñar et al. 2013). Fungi showed less diversity than bacteria, and species of the genera Aspergillus, Cladosporium, and Phoma were dominant (Carmona et al. 2006; Piñar et al. 2013). Thus, historical glass windows are a habitat in which both fungi and bacteria form complex microbial consortia of high diversity. The bacteria are genetically similar to those that cause mineral precipitation on stones. Regarding the detected fungi, they are ubiquitous 
airborne species. According to Piñar and coauthors (2013), the pitting present on the surfaces of glass windows could relate to other more specialized fungi that grew in the past and are not detectable now.

The chemical composition of the glass affects microbial development; copper contained in green glasses acts as an inhibitor (Marvasi et al. 2009; Piñar et al. 2013). In a laboratory test, historically accurate reconstructions of glass windows (fifteenth and seventeenth centuries, Sintra, Portugal) were inoculated with fungi of the genera Cladosporium and Penicillium previously isolated from the original stained-glass windows. The fungi produced clear damage on glass surfaces in form of stains, erosion, pitting, crystals, and leaching (Rodrigues et al. 2014).

Biofilms on modern glasses may alter their transparency (Shirakawa et al. 2016) and smoothness (Corrêa Pinto et al. 2019). However, Na-rich glass samples inoculated with a mixture of four fungal species showed high resistance against the microorganisms' growth (Corrêa Pinto et al. 2019).

\subsection{Metals}

Physicochemical interactions between a metallic material and its environment can lead to electrochemical corrosion. It is a chemical reaction that occurs when electrons from metal are transferred to an external electron acceptor, causing release of the metal ions into the surrounding medium and deterioration of the metal (Beech and Sunner 2004). This process consists of a series of oxidation (anodic) and reduction (cathodic) reactions of compounds present in direct contact with or in proximity to the metallic surface (Beech and Sunner 2004). The rate of the metal deterioration decreases gradually with time, because the oxidation products (for example, oxidation of metallic iron to $\mathrm{Fe}^{2+}$ ion) adhere to the surface forming a protective layer that provides a diffusion barrier to the reactants.

Biocorrosion or microbiologically influenced corrosion (MIC) is caused by the interaction between the metal surface, abiotic corrosion products, and microbial cells and their metabolites. MIC is an electrochemical process in which microorganisms initiate, facilitate, or accelerate a corrosion reaction on a metal surface through the utilization and release of electrons (Kadukova and Pristas 2018). Microbial activity of biofilms present on surfaces of metallic objects may affect the kinetics of cathodic and/or anodic reactions and may also considerably modify the chemistry of any protective layers (Beech and Sunner 2004). Recent evidence indicates that bacteria can transport electrons via organic molecules of the surrounding environment (Gu 2019).

Most investigations have addressed the impact of biofilms on corrosion behavior of iron, copper, aluminum, and their alloys. The effects of microbial activity on iron or steel range from pitting, crevice formation, under-deposit corrosion to stress corrosion cracking (Aramendia et al. 2015).

Microorganisms mostly involved in the biocorrosion of metals are aerobic and anaerobic bacteria (Zanardini et al. 2008). In open air systems, anaerobic corrosion 
still occurs if a corrosive anaerobic biofilm grows underneath a top aerobic biofilm (Xu et al. 2016). While in oxic environments metal corrosion is a fast process that can be enhanced by microorganisms, under anoxic conditions it would take very long time without the help of microorganisms (Kadukova and Pristas 2018).

Anaerobic sulfate reducing bacteria (SRB) have been considered key culprits in MIC of a wide range of industrial structures because the sulfur cycle is linked to microbial metabolism, affecting the integrity of metals (Beech et al. 2014; Rémazeilles et al. 2010). Indeed, one of the most known phenomena is the production of sulfides induced in anoxic environments by SRB (Aramendia et al. 2015). However, also other types of bacteria have been associated with metals in terrestrial and aquatic habitats-sulfur oxidizing bacteria, iron oxidizing/reducing bacteria, manganese-oxidizing bacteria, nitrate reducing bacteria and bacteria secreting organic acids and slime (Beech and Coutinho 2003; Xu et al. 2016; Kadukova and Pristas 2018). Regarding the influence of SRB in the corrosion of iron, it has been documented that not only different genera of these organisms but also species within the same genus vary in their ability to deteriorate iron (Beech et al. 2014).

Extracellular polymeric substances are able to bind metal ions. This property is important to MIC and depends both on bacterial species and on the type of metal ion (Kinzler et al. 2003). Metal binding by EPS involves interaction between the metal ions and anionic functional groups (e.g. carboxyl, phosphate, sulfate, glycerate, pyruvate, and succinate groups) that are commonly present on the protein and carbohydrate components of EPS. In particular, the affinity of multidentate anionic ligands for multivalent ions, such as $\mathrm{Ca}^{2+}, \mathrm{Cu}^{2+}, \mathrm{Mg}^{2+}$, and $\mathrm{Fe}^{3+}$, can be very strong (Beech and Sunner 2004).

Biocorrosion is recognized as an important category of corrosion leading to important economic loss in many industries and services including oil and gas pipelines, water utilities and the power generation industry (Xu et al. 2016; Eid et al. 2018). Therefore, MIC has been the subject of extensive studies on these systems for the past decades and several models have been proposed to explain mechanisms governing biocorrosion (Beech and Sunner 2004). Regarding cultural heritage objects, many papers documented the role of microorganisms in corrosion of metal artifacts (Brown and Masters 1980; Dhawan 1987; Gilbert 1987; McNeil et al. 1991; Sánchez del Junco et al. 1992; Little et al. 1998; Rémazeilles et al. 2010; Aramendia et al. 2015). MIC is associated to the presence of anaerobic SRBs on the surfaces of archaeological objects recovered from terrestrial and aquatic environments (Sánchez del Junco et al. 1992). Regarding buried metal objects, it is worth mentioning that the degree of preservation of them in soil is specific to the type of metal (Kibblewhite et al. 2015). Ag is less resistant to corrosion than Au but more than $\mathrm{Cu}$ while $\mathrm{Zn}$ corrodes faster. $\mathrm{Cu}$ artefacts may contain $\mathrm{As}$, and this element is also commonly a minor constituent of bronze (an alloy of $\mathrm{Cu}$ and $\mathrm{Sn}$, which is more resistant to corrosion than pure $\mathrm{Cu}$ ). $\mathrm{Fe}$ is much more easily corroded than $\mathrm{Cu}$, while $\mathrm{Pb}$ is resistant to corrosion in most aqueous environments. Aluminum forms a protective surface oxide coating that gives it some resistance to oxidative corrosion (Kibblewhite et al. 2015). Degradation rates of these materials (e.g. Fe) can be influenced by the soil type. Sulfide and disulfide ions generated by SRB in soils 

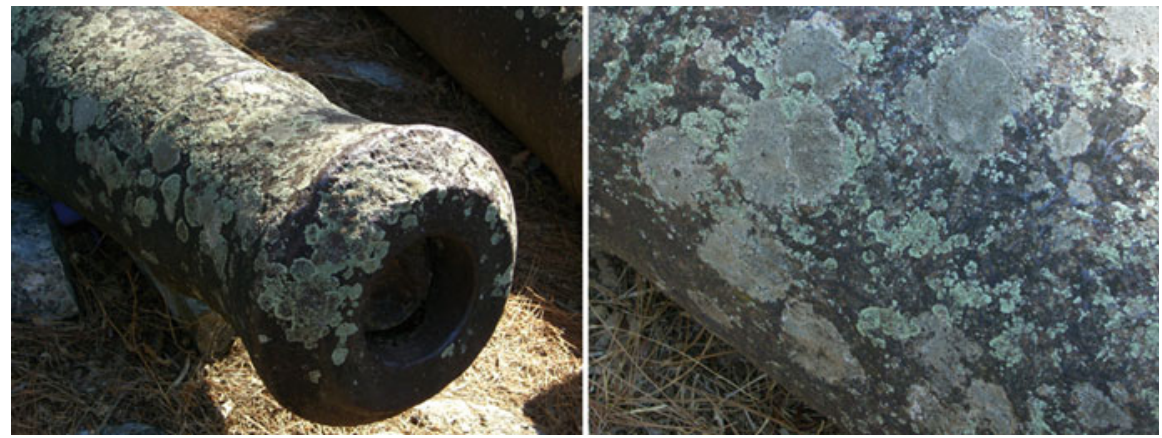

Fig. 1.6 Widespread lichen colonization on metals. Ancient cannon, Ioannina, Greece (left). A close-up of the colonized metal surface (right)

enhance the corrosive activity of chloride ions. Moreover, biogenic sulfides may be used as alternative substrates in the cathodic reaction at low oxygen concentration (Sánchez del Junco et al. 1992). Biocorrosion of objects in soil can be markedly accelerated by alternate anaerobic and aerobic conditions. Sulfides formed by SRB in anaerobic conditions are transformed to polysulfides, and sulfur and ferric sulfates when soil $\mathrm{pH}$ decreases.

The formation of black corrosion stains containing sulfides on copper alloy buried objects was attributed to SRB, prevalent in those soils, through the production of hydrogen sulfide (Sánchez del Junco et al. 1992).

Some studies have focused on the involvement of fungi in the MIC. The development of Aspergillus niger accelerated the corrosion process (severe pitting corrosion and aluminum depletion accompanied with copper enrichment) of aluminum alloy 2024 samples in a laboratory experiment (Dai et al. 2016). The corrosion rate was four times greater than that of samples exposed to $3.5 \mathrm{wt} \% \mathrm{NaCl}$ solution. Oxalic acid, identified as the dominant metabolite of Aspergillus niger, caused the corrosion. The same compound formed iron oxalates and calcium oxalates on the surface of parts of a weathering steel sculpture (Aramendia et al. 2015). Irregularities and discolorations of the object were thus caused by oxalic acid excreted by microorganisms growing on the steel surface.

To the best of my knowledge, no studies have been carried out yet on the interaction of lichens with metallic works of art. As illustrated in Fig. 1.6, crustose lichens completely cover a metal object. Thus, carrying out these studies would be beneficial.

While most studies have documented the negative aspects of the biofilms' development on metallic materials, an emerging topic deals with a positive aspect of this interaction, that is corrosion inhibition. The mechanisms involved are supposed to be the neutralization of the action of environmental corrosive substances (e.g. acidic compounds), and the formation of protective films or the stabilization of preexisting protective films on a metal (e.g. EPS cohesive effects) (Videla and Herrera 2009). Both mechanisms are linked to a marked modification of the 
environmental conditions at the metal/solution interface due to biological activity. However, the inhibitory action of bacteria may change to the contrary, that is to a corrosive action by other bacteria located within the biofilm (Videla and Herrera 2009). Therefore, the corrosive and the inhibitory actions of bacteria can coexist at the metal surfaces where complex biofilm/protective films interactions occur.

\section{Bioprotection of Stones by Biofilms and Lichens}

The damaging capability of biofilms and lichens on rock art and monuments has been documented, as previously mentioned. Nonetheless, recent research has provided increasing evidence of a minor effect and even of protection. Therefore, the correlation among biofilms, lichens and stone deterioration is no longer being considered an axiom (Pinna 2014). Their presence on works of art does not automatically indicate a change in the physicochemical properties of the materials. A study on petroglyphs colonized by lichens demonstrated, for example, that the organisms were not one of the key factors to define their state (Chiari and Cossio 2004). Lichens neither acted damaging the outermost layer of the sandstones nor protecting them from rain, sun, etc. Lichens filled the micro-fissures between the grains, which were large enough to hold them without exerting relevant pressure. In that way lichens filled the pores so that the porosity of the outer layer was the same as in the bulk of the rock. The deterioration of the sandstone related mainly to the nature of the sandstone itself, particularly to the dimension of the quartz grains: the larger the grains, the greater the porosity, and consequently water absorption, fragility, and decohesion of the rock.

Phototrophic biofilms colonizing marbles of the cathedral of Monza (Italy) did not affect the stones that were instead altered by meteoric waters, wind, solar radiation, and large thermal excursions (Gulotta et al. 2018). The environmental exposure was the main cause of damage of the marbles. Moreover, two types of marble showed the most intense surface decay in the uncolonized areas.

Lithobionts, mainly lichens, have been suggested to temporarily stabilize porous and loosely to moderately cemented stones. Case hardened surfaces that develop over tuff outcrops in Frijoles Canyon (Bandelier National Monument, New Mexico, USA) are a combination of biotic and abiotic crusts that contribute to the preservation of ancient rock-cut caves called cavates (derived from the words "cave" and "excavate"), which were used as dwelling, storage, and special-purpose rooms by the Native American Pueblos (Porter et al. 2016). Lichen cover improved the weather resistance of the tuff and provided some degree of protection to archaeological resources carved in the rock. The lichen cover formed a barrier layer shielding rock surfaces from water flow, wind abrasion, and temperature variation, resulting in reduced weathering rates (Porter et al. 2016). The results were supported by in situ measures of the volume of water absorbed by the rock through time and of surface gas permeability. According to the authors, surface improvements occurred as the result of two different processes: (1) colonization of outcrop surfaces by 
cyanobacteria, lichens, and other biota cemented wind-blown and water-transported particles to the rock face through secretion of sticky polysaccharides; the formation of dense networks of filaments infiltrated, reinforced, and stabilized the accumulated clay/silt coatings, and shielded the loose ash inside the tuff from wind- and waterdriven actions; (2) excretion of organic acids by biotic crust catalyzed biogeochemical reactions that led to the dissolution of fine volcanic glass and cementation of the tuff surface by precipitation of secondary minerals in the network of interconnected pores. Both processes result in occlusion of pores at the surface.

Some studies reported similar benefits conferred by lichen/biofilm cover on various types of rocks. Lichens may provide protection against the natural decay of porous stones either by decreasing the intensity of water exchanges between substrata and environment or by diminishing the damage caused by atmospheric agents (wind, rain, pollutants, salt aerosol) (Ariño et al. 1995; Wendler and Prasartet 1999; Carballal et al. 2001; Bungartz et al. 2004; Gadd and Dyer 2017). More widespread exfoliation, saline efflorescence, flaking, and honeycombing of uncolonized surfaces supported this hypothesis. Lichens may provide thermal blanketing, absorb aggressive chemicals, keep surfaces hot and dry more constantly, reduce boundary layer wind speed, limit erosion and thermal tress (Garcia-Vallès et al. 2003; Carter and Viles 2003; Casanova Municchia et al. 2018).

After the removal of crustose epilithic lichens on marble and sandstone in the archaeological site of Fiesole (Italy), in situ water absorption measurements were carried out (Pinna et al. 2018). Both substrata showed a quite low absorption capacity, which was even close to that of the healthy substrata. The only alteration detected on the stones was that of epilithic crustose lichens forming a uniform and continuous coverage that could have acted as a protective barrier for the substrata, protecting them from abiotic weathering.

Epilithic and endolithic lichens affected hardness and water absorption of Portland and Botticino limestones. Measures of surface hardness and water absorption capacity/infiltration rates were carried out before and after the removal of lichens (Morando et al. 2017). The observed water absorption increase was caused by porosity alteration due to endolithic lichens action. By contrast, the lichen-rock interface revealed unmodified or even increased hardness of the limestones, related to lower weathering rates. According to the authors, these results suggest the opportunity to investigate if and how hardening patterns may also accompany lichen biogeochemical processes on limestones (Morando et al. 2017).

An experimental study showed that endolithic lichens substantially reduced loss of material from a limestone surface (Fiol et al. 1996). Two types of limestone samples, taken from bare natural outcrops and from rocks covered with endolithic lichens, were exposed to artificial conditions in the laboratory, simulating rainstorm using distilled water. The analysis of run-off water showed that the loss of mineral grains and dissolved compounds from the bare limestone surface was substantially higher than that from the lichen-covered surface, suggesting that a process of bioprotection may took place.

According to Hoppert and König (2006), the ecology of succession of biofilms and lichens on stones is the key to explain the phenomenon. Microorganisms 
characterized by fast-growing ability and short reproductive cycle are more likely to be deteriorative, because they colonize rapidly after disturbance (sporadic events affecting community structure and dynamics, e.g., fire, drought, storms, or erosion) or stress conditions (e.g. increasing temperature and UV levels, decreasing moisture levels), and use a range of strategies to obtain nutrients from the substratum. Such strategies may cause further change of the surface through weathering. In an advanced state of biofilm development, these microorganisms are replaced by colonizers with different life strategies. These "new" colonizers are biofilms and lichens characterized by moderate metabolic and reproductive rates. In order to develop and colonize the rock, they need that the stone is not rapidly decomposed. Therefore, they "protect" the stone forming a compact network of cells and extracellular polymers, which surround and enwrap the mineral particles. This biogenic structure temporarily stabilizes the stone and reduces weathering, enabling biofilms and lichens to growth and persist over several years or even decades (Hoppert and König 2006).

Bioprotection by lichens may relate to environmental parameters. Carter and Viles (2005) suggested that a single species may act protectively in one environmental context but can be deteriorative in another. For example, the epilithic crustose lichen Verrucaria nigrescens is common in Europe in both wet and dry climates. In wet conditions, the lichen may act as a bioprotector, shielding the stone from the direct action of rainfall, acid attack, wind, runoff, and dissolution. In a hotter and drier context, where there are extreme temperatures, Verrucaria nigrescens may have instead a dominant biodeteriorative impact, intensifying temperature fluctuations at the rock surface and possibly leading to thermal stress.

According to McIlroy de la Rosa and coauthors (2013), active bioprotection of a rock surface by crustose lichens is determined primarily by how the thalli are attached to the substratum, by their binding and waterproofing action and whether they provide an effective shield. The production of insoluble substances (usually calcium oxalates) at the lichen-rock interface provides a passive protection of the rock.

The results of the mentioned studies have even led Gadd and Dyer (2017) to suggest actions for promoting the growth of biofilms and lichens on stone surfaces as the biogenic approach is an environmentally friendly method for protection of stones.

A general consideration emerging from the literature so far is that biodeterioration and bioprotection by lichens coexist in a delicate equilibrium that can be destabilized by environmental changes. According to Morando et al. (2017), deterioration caused by the growth of lichen hyphae in limestones is likely counterbalanced by a protective effect on the rock surface by the covering of epilithic and endolithic species. They shelter and protect the substratum from more aggressive abiotic weathering agents limiting erosion processes.

Despite significant research efforts, there are still many general issues that need to be investigated. A homogeneous coverage of crustose lichens on stone surfaces is usually formed by many species growing close each other. Some of them can be overall protective, other can be overall deteriorative and other can have a negligible 
effect, resulting in differences of the spatial distribution of surface biomodifications. This mélange of situations is difficult to manage from a conservative point of view. In another scenario the surfaces are colonized by few little lichen thalli surrounded by biofilms. What happens in this situation? Are just some little areas protected while others are not? Furthermore, even a single lichen thallus can have either a protective or a deteriorative action within the same thallus (Mottershead and Lucas 2000).

The mentioned studies attribute bioprotective properties to epilithic and endolithic crustose lichens. However, there are crustose lichens like those belonging to Lepraria genus that do not form a continuous layer over the substratum. In that case it is unlikely they act as a local shield. In addition, atmospheric factors (e.g. moisture, temperature, and insolation) affect lichen metabolic activity and, consequently, their impact on the substratum, including their protective role. Climate changes alter the structure and function of microbial communities as well. According to Viles and Cutler (2012), areas where increased frequency of climatic disturbances will likely occur, will be subjected to biodeteriorative effects for the same reasons previously discussed about the ecology of succession of biofilms and lichens on stones. On the contrary, areas where increased stresses will occur are likely to be colonized by microorganisms adapted to persist in low-resource environments. In such a context, there will be a strong decrease of biodeterioration.

Another gap in our knowledge of bioprotection effects on stones by biofilms and lichens derives from the fact that the mentioned studies applied different methods to assess the protective properties of lichens, therefore their results are not comparable. The assessment of standard test methods and procedures to evaluate the protective and/or damaging action by biofilms and lichens is crucial for future studies on this subject.

Further research is required to understand the importance of microbial ecology in biodeteriorative vs bioprotective effects (i.e. the difference between actively altering and non-altering microbial communities on stones exposed to the same environment). New lines of research proposed by Villa and coauthors (2016) will help explain these issues. Viewing the biofilms from an ecological perspective, new studies should deal with a system-level approach which is potentially very valuable in understanding the functional capacities and adaptive potentials that drive aggregation and survival of microbial communities on stones (Villa et al. 2016). The study of functional traits (morphological, biochemical, physiological, structural, phenological, or behavioral features) will contribute to shed light on the interaction of microorganisms with their environment and with stones (Villa et al. 2016). These advances will also help explain how such aspects affect spatial and temporal distributions of biotic and abiotic reactions. Ongoing research in understanding the bioprotective vs biodeteriorative role of biofilms and lichens will also lead to make suggestions regarding the actions that should or should not be taken to retard deterioration and enhance protection of monuments (Jacob et al. 2018). 


\section{References}

Abuku M, Janssen H, Roels S (2009) Impact of wind-driven rain on historic brick wall buildings in a moderately cold and humid climate: numerical analyses of mould growth risk, indoor climate and energy consumption. Energ Buildings 41:101-110

Adamson C, McCabe S, Warke PA, McAllister D, Snith BJ (2013) The influence of aspect on the biological bolonization of stone in Northern Ireland. Int Biodeterior Biodegradation 84:357-366

Albertano P, Bruno L, Bellezza S (2005) New strategies for the monitoring and control of cyanobacterial films on valuable lithic faces. Plant Biosyst 139:311-322

Allsopp D, Seal K, Gaylarde C (2004) Introduction to biodeterioration. Cambridge University Press, Cambridge

Aramendia J, Gomez-Nubla L, Bellot-Gurlet L, Castro K, Arana G, Madariaga JM (2015) Bioimpact on weathering steel surfaces: oxalates formation and the elucidation of their origin. Int Biodeterior Biodegradation 104:59-66

Ariño X, Ortega-Calvo JJ, Gomez-Bolea A, Saiz-Jimenez C (1995) Lichen colonization of the Roman pavement at Baelo Claudia (Cadiz, Spain): biodeterioration vs bioprotection. Sci Total Environ 67:353-363

Ashbee J (2010) Ivy and the presentation of ancient monuments and building. In: Sternberg T (ed) Ivy on Walls, Seminar Report, English Heritage, pp 9-15

Bastian F, Jurado V, Nováková A, Alabouvette C, Saiz-Jimenez C (2010) The microbiology of Lascaux Cave. Microbiology 156:644-652

Beech IB, Coutinho CLM (2003) Biofilms on corroding materials. In: Lens P, Moran AP, Mahony T, Stoodly P, O'Flaherty V (eds) Biofilms in medicine, industry and environmental biotechnology - characteristics, analysis and control. IWA Publishing of Alliance House, London, pp 115-131

Beech IB, Sunner J (2004) Biocorrosion: towards understanding interactions between biofilms and metals. Curr Opin Biotechnol 15:181-186

Beech IB, Sztyler M, Gaylarde CC, Smith WL, Sunner J (2014) Biofilms and biocorrosion. In: Liengen T, Feron D, Basseguy R, Beech IB (eds) Understanding biocorrosion: fundamentals and applications. Woodhead Publishing, Cambridge, pp 33-50

Bjelland TH, Thorseth IH (2002) Comparative studies of the lichen-rock interface of four lichens in Vingen, Western Norway. Chem Geol 192:81-98

Bridier A, Piard J-C, Pandin C, Labarthe S, Dubois-Brissonnet F, Briandet R (2017) Spatial organization plasticity as an adaptive driver of surface microbial communities. Front Microbiol 8:1364

Brown PW, Masters LW (1980) Factors affecting the corrosion of metals in the atmosphere. In: Ailor WH (ed) Atmospheric corrosion. John Wiley and Sons, New York, pp 31-49

Bungartz F, Garvie LAJ, Nash TH (2004) Anatomy of the endolithic Sonoran Desert lichen Verrucaria rubrocincta Breuss: implications for biodeterioration and biomineralization. Lichenologist 36:55-73

Cámara B, Suzuki S, Nealson KH, Wierzchos J, Ascaso C, Artieda O, de los Ríos A (2014) Ignimbrite textural properties as determinants of endolithic colonization patterns from hyperarid Atacama Desert. Int Microbiol 17:235-247

Caneva G, Bartoli F (2017) Botanical planning and lichen control for the conservation of gravestones in Jewish urban cemeteries in North-Eastern Italy. Israel J Plant Sci 64:1-14

Caneva G, Ceschin S (2008) Ecology of biodeterioration. In: Caneva G, Nugari MP, Salvadori O (eds) Plant biology for cultural heritage: biodeterioration and conservation. Getty Conservation Institute, Los Angeles, pp 35-58

Cappitelli F, Abbruscato P, Foladori P, Zanardini E, Ranalli G, Principi P, Villa F, Polo A, Sorlini C (2009) Detection and elimination of cyanobacteria from frescoes: the case of the St. Brizio Chapel (Orvieto Cathedral, Italy). Microbial Ecol 57:633-639 
Carballal R, Paz-Bermúdez G, Sánchez-Biezma MJ, Prieto B (2001) Lichen colonization of coastal churches in Galicia: biodeterioration implications. Int Biodeterior Biodegradation 47:157-163

Carmona N, Laiz L, Gonzalez JM, Garcia-Herasa M, Villegasa MA, Saiz-Jimenez C (2006) Biodeterioration of historic stained glasses from the Cartuja de Miraflores (Spain). Int Biodeterior Biodegradation 58:155-161

Carter NEA, Viles HA (2003) Experimental investigations into the interactions between moisture, rock surface temperatures and an epilithic lichen cover in the bioprotection of limestone. Build Environ 38:1225-1234

Carter NEA, Viles HA (2005) Bioprotection explored: the story of a little known earth surface process. Geomorphology 67:273-281

Casanova Municchia A, Bartoli F, Taniguchi Y, Giordani P, Caneva G (2018) Evaluation of the biodeterioration activity of lichens in the Cave Church of Üzümlü (Cappadocia, Turkey). Int Biodeterior Biodegradation 127:160-169

Chiari G, Cossio R (2004) Lichens of Wyoming sandstone, do they cause damage? In: St. Clair L, Seawards M (eds) Biodeterioration of rock surfaces. Kluwer Academic Publishers, Dordrecht, pp 99-113

Corrêa Pinto AM, Palomar T, Alves LC, da Silva SHM, Monteiro RC, Macedo MF, Vilarigues MG (2019) Fungal biodeterioration of stained-glass windows in monuments from Belém do Pará (Brazil). Int Biodeterior Biodegradation 138:106-113

Cutler NA, Viles HA, Ahmad S, McCabe S, Smith BJ (2013) Algal 'greening' and the conservation of stone heritage structures. Sci Total Environ 442:152-164

Dai X, Wang H, Ju LK, Cheng G, Cong H, Newby BMZ (2016) Corrosion of aluminum alloy 2024 caused by Aspergillus niger. Int Biodeterior Biodegradation 115:1-10

De Leo F, Urzì C, de Hoog GSA (2003) New meristematic fungus, Pseudotaeniolina globosa. Antonie Van Leeuwenhoek 83:351-360

de Los Rios A, Wierzchos J, Ascaso C (2002) Microhabitats and chemical microenvironments under saxicolous lichens growing on granite. Microb Ecol 43:181-188

de los Rios A, Cámara B, García del Cura MA, Rico VJ, Galván V, Ascaso C (2009) Deteriorating effects of lichen and microbial colonization of carbonate building rocks in the Romanesque churches of Segovia (Spain). Sci Total Environ 407:1123-1134

Dhawan S (1987) Role of microorganisms in corrosion of metals - a literature survey. In: Agrawal OP (ed) Asian regional seminar on conservation of metals in humid climates. ICCROM, Roma, pp 100-102

Di Martino P (2016) What about biofilms on the surface of stone monuments? Open Confer Proc J 6:14-28

Diao M, Taran E, Mahler S, Nguyen AV (2014) A concise review of nanoscopic aspects of bioleaching bacteria-mineral interactions. Adv Colloid Interf Sci 212:45-63

Dupraz C, Reid RP, Braissant O, Decho AW, Norman RS, Visscher PT (2009) Processes of carbonate precipitation in modern microbial mats. Earth-Sci Rev 96:141-162

Edwards HGM, Seaward MRD, Attwood SJ, Little SJ, De Oliveira LFC, Tretiach M (2003) FT-Raman spectroscopy of lichens on dolomitic rocks: an assessment of metal oxalate formation. Analyst 128:1218-1221

Eid MM, Duncan KE, Tanner RS (2018) A semi-continuous system for monitoring microbially influenced corrosion. J Microbiol Methods 150:55-60

Elhagrassy AF (2018) Isolation and characterization of actinomycetes from mural paintings of SnuSert-Ankh tomb, their antimicrobial activity, and their biodeterioration. Microbiol Res 216:47-55

Favero-Longo SE, Borghi A, Tretiach M, Piervittori R (2009) In vitro receptivity of carbonate rocks to endolithic lichen-forming aposymbionts. Mycol Res 113:1216-1227

Favero-Longo SE, Gazzano C, Girlanda M, Castelli D, Tretiach M, Baiocchi C, Piervittori R (2011) Physical and chemical deterioration of silicate and carbonate rocks by meristematic microcolonial fungi and endolithic lichens (Chaetothyriomycetidae). Geomicrobiol J 28:732-744 
Fiol L, Fornós JJ, Ginés A (1996) Effects of biokarstic processes on the development of solutional rillenkarren in limestone rocks. Earth Surf Process Landf 21:447-452

Flemming HC, Wingender J, Szewzyk U, Steinberg P, Rice SA, Kjelleberg S (2016) Biofilms: an emergent form of bacterial life. Nat Rev Microbiol 14:563-575

Fomina M, Burford EP, Hillier S, Kierans M, Gadd GM (2010) Rock-building fungi. Geomicrobiol J 27:624-629

Gadd GM, Dyer TD (2017) Bioprotection of the built environment and cultural heritage. Microb Biotechnol 10:1152-1156

Gadd GM, Bahri-Esfahani J, Li Q, Rhee YJ, Wei Z, Fomina M, Liang X (2014) Oxalate production by fungi: significance in geomycology, biodeterioration and bioremediation. Fungal Biol Rev 28:36-55

Garcia-Vallès M, Topal T, Vendrell-Saz M (2003) Lichenic growth as a factor in the physical deterioration or protection of Cappadocian monuments. Environ Geol 43:776-781

Gilbert M (1987) Black spots on bronzes. Newsletter ICOM Committee for Conservation, Metal Working Group, 3:12

Gittins M, Vedovello S, Dvalishvili M, Kuprashvili N (2002) Determination of the treatment and restoration needs of medieval frescos in Georgia. In: Proceeding of ICOM-CC 13th triennial meeting, Rio de Janeiro, Brazil, pp 560-564

Golubic S, Pietrini AM, Ricci S (2005) Euendolithic activity of the cyanobacterium Chroococcus lithophilus Erc. in biodeterioration of the pyramid of Caius Cestius, Rome, Italy. Int Biodeterior Biodegradation 100:7-16

González-Gómez WS, Quintana P, Gómez-Cornelio S, García-Solis C, Sierra-Fernandez A, Ortega-Morales O, De la Rosa-García SC (2018) Calcium oxalates in biofilms on limestone walls of Maya buildings in Chichén Itzá, Mexico. Environ Earth Sci 77: 230

Gorbushina AA (2007) Life on the rocks. Environ Microbiol 9:1613-1631

Gu JD (2019) Corrosion, microbial. In: Schmidt T (ed) Encyclopedia of microbiology, 4th edn. Elsevier, Amsterdam, pp 762-771

Guillitte O (1985) Bioreceptivity: a new concept for building ecological studies. Sci Total Environ 167:215-220

Gulotta D, Villa F, Cappitelli F, Toniolo L (2018) Biofilm colonization of metamorphic lithotypes of a renaissance cathedral exposed to urban atmosphere. Sci Total Environ 639:1480-1490

Hentzer M, Eberl L, Nielsen J, Givskov M (2003) Quorum sensing: a novel target for the treatment of biofilm infections. BioDrugs 17:241-250

Hoffland E, Kuyper TW, Wallander H, Plassard C, Gorbushina AA, Haselwandter H, Holmstrom S, Landeweert R, Lundstrom US, Rosling A, Sen R, Smits MM, van Hees PAW, van Breemen N (2004) The role of fungi in weathering. Front Ecol Environ 2: 258-264

Hoppert M, König S (2006) The succession of biofilms on building stone and its possible impact on biogenic weathering. In: Fort R, Alvarez de Buergo M, Gomez-Heras M, Vazquez-Calvo C (eds) Heritage, weathering and conservation. Taylor \& Francis Group, London, pp 311-315

Jacob JM, Schmull M, Villa F (2018) Biofilms and lichens on eroded marble monuments. APT Bull 49:55-60

Jain A, Bhadauria S, Kumar V, Chauhan RS (2009) Biodeterioration of sandstone under the influence of different humidity levels in laboratory conditions. Build Environ 44:1276-1284

Jurado V, Laiz L, Sanchez-Moral S, Saiz-Jimenez C (2014) Pathogenic microorganisms related to human visits in Altamira Cave, Spain. In: Saiz-Jimenez C (ed) The conservation of subterranean cultural heritage. CRC Press/Balkema, Leiden pp. 229-238

Kadukova J, Pristas P (2018) Biocorrosion - microbial action. In: Wandelt K (ed) Encyclopedia of interfacial chemistry: surface science and electrochemistry. Elsevier, Amsterdam, pp 20-22

Katharios-Lanwermeyer S, Xi C, Jakubovics NS, Rickard AH (2014) Mini-review: microbial coaggregation: ubiquity and implications for biofilm development. Biofouling 30:1235-1251

Kibblewhite M, Tóth G, Tamás Hermann T (2015) Predicting the preservation of cultural artefacts and buried materials in soil. Sci Total Environ 529:249-263 
Kinzler K, Gehrke T, Telegdi J, Sand W (2003) Bioleaching - a result of interfacial processes caused by extracellular polymeric substances (EPS). Hydrometallurgy 71:83-88

Konhauser K (2007) Introduction to geomicrobiology. Blackwell, Oxford

Kyi C (2006) The significance of appropriate sampling and cultivation in the effective assessment of biodeterioration. Z Kunsttechnol Konservierung 20:344-351

Little B, Wagner P, Hart K (1998) The role of biomineralization in microbiologically influenced corrosion. Biodegradation 9:1-10

Liu W, Order HL, Madsen JS, Bjarnsholt T, Sorensen SJ, Burmolle M (2016) Interspecific bacterial interactions are reflected in multispecies biofilm spatial organization. Front Microbiol 7:1366

Lombardozzi V, Castrignanò T, D 'Antonio M, Casanova Municchia A, Caneva G (2012) An interactive database for an ecological analysis of stone biopitting. Int Biodeterior Biodegradation 73:8-15

López D, Vlamakis H, Kolte R (2010) Biofilms. Cold Spring Harb Perspect Biol 2:a00398

Marvasi M, Vedovato E, Balsamo C, Macherelli A, Dei L, Mastromei G, Perito B (2009) Bacterial community analysis on the mediaeval stained-glass window 'Nativita' in the Florence cathedral. J Cult Heritage 10:124-133

Marvasi M, Donnarumma F, Frandi A, Mastromei G, Sterflinger K, Tiano P, Perito B (2012) Black microcolonial fungi as deteriogens of two famous marble statues in Florence, Italy. Int Biodeterior Biodegradation 68:36-44

Mcllroy de la Rosa JPM, Warke PA, Smith BJ (2013) Lichen-induced biomodification of calcareous surfaces: bioprotection versus biodeterioration. Progr Phys Geogr 37:325-351

McNeil MB, Mohr DW, Little BJ (1991) Correlation of laboratory results with observations on long-term corrosion of iron and copper alloys. In: Vandiver PB, Druzik J, Wheeler GS (eds) 2nd Symposium on materials issues in art and archaeology, San Francisco, USA, pp 753-759

Miller AZ, Laiz L, Dionísio A, Macedo MF (2006) Primary bioreceptivity: a comparative study of different Portuguese lithotypes. Int Biodeterior Biodegradation 57:136-142

Miller AZ, Dionísio A, Sequeira Braga MA, Hernández-Mariné M, Afonso MJ, Muralha VSF, Herrera LK, Raabe J, Fernandez-Cortes A, Cuezva S, Hermosin B, Sanchez-Moral S, Chaminé H, Saiz-Jimenez C (2012a) Biogenic Mn oxide minerals coating in a subsurface granite environment. Chem Geol 322-323:181-191

Miller AZ, Sanmartín P, Pereira-Pardo L, Dionísio A, Sáiz-Jiménez C, Macedo MF, Prieto B (2012b) Bioreceptivity of building stones: a review. Sci Total Environ 426:1-12

Mittelmann MW (2018) The importance of microbial biofilms in the deterioration of heritage materials. In: Mitchell R, Clifford J (eds) Biodeterioration and preservation in art, archaeology and architecture. Archetype Publications, London, pp 3-15

Miura S (2006) Conservation of mural paintings of the Takamatsuzuka tumulus and its current situation. In: Yamauchi K, Taniguchi Y, Uno T (eds) Mural paintings of the silk road: cultural exchanges between east and west. Archetype Publications Ltd, Tokio, pp 127-130

Morando M, Wilhelm K, Matteucci E, Martire L, Piervittori R, Viles HA, Favero-Longo SE (2017) The influence of structural organization of epilithic and endolithic lichens on limestone weathering. Earth Surf Process Landforms 42:1666-1679

Mottershead D, Lucas G (2000) The role of lichens in inhibiting erosion of a soluble rock. Lichenologist 32:601-609

Noeiaghaei T, Mukherjee A, Dhami N, Chae SR (2017) Biogenic deterioration of concrete and its mitigation technologies. Construct Building Mater 149:575-586

Nugari MP, Pietrini AM, Caneva G, Imperi F, Visca P (2009) Biodeterioration of mural paintings in a rocky habitat: the crypt of the Original Sin (Matera, Italy). Int Biodeterior Biodegradation 63:705-711

Olsson-Francis K, Simpson AE, Wolff-Boenisch D (2012) The effect of rock composition on cyanobacterial weathering of crystalline basalt and rhyolite. Geobiology 10:434-444

Onofri S, Zucconi L, Isola D, Selbmann L (2014) Rock-inhabiting fungi and their role in deterioration of stone monuments in the Mediterranean area. Plant Biosyst 148:384-391 
Ortega-Morales BO, Narváez-Zapata J, Reyes-Estebanez M, Quintana P, de la Rosa-García SC, Bullen H, Gómez-Cornelio S, Chan-Bacab MJ (2016) Bioweathering potential of cultivable fungi associated with semi-arid surface microhabitats of Mayan buildings. Front Microbiol 7:201

Pangallo D, Kraková L, Chovanová K, Šimonovičová A, de Leo F, Urzì C (2012) Analysis and comparison of the microflora isolated from fresco surface and from surrounding air environment through molecular and biodegradative assays. World J Microbiol Biotech 28:2015-2027

Piñar G, Garcia-Valles M, Gimeno-Torrente D, Fernandez-Turiel JL, Ettenauer J, Sterflinger K (2013) Microscopic, chemical, and molecular-biological investigation of the decayed medieval stained window glasses of two Catalonian churches. Int Biodeterior Biodegradation 84:388-400

Pinna D (2014) Biofilms and lichens on stone monuments: do they damage or protect? Front Microbiol 5:1-3

Pinna D (2017) Coping with biological growth on stone heritage objects. Methods, products, applications, and perspectives. Apple Academic Press, Palm Bay

Pinna D, Salvadori O (2008) Biodeterioration processes in relation to cultural heritage materials. Stone and related materials. In: Caneva G, Nugari MP, Salvadori O (eds) Plant biology for cultural heritage. The Getty Conservation Institute, Los Angeles, pp 128-143

Pinna D, Salvadori O, Tretiach M (1998) An anatomical investigation of calcicolous endolithic lichens from the Trieste karst (NE Italy). Plant Biosyst 132:183-195

Pinna D, Salvadori B, Galeotti M (2012) Monitoring the performance of innovative and traditional biocides mixed with consolidants and water-repellents for the prevention of biological growth on stone. Sci Total Environ 423:132-141

Pinna D, Galeotti M, Perito B, Daly G, Salvadori B (2018) In situ long-term monitoring of recolonization by fungi and lichens after innovative and traditional conservative treatments of archaeological stones in Fiesole (Italy). Int Biodeterior Biodegradation 132:49-58

Pohl W, Scheider J (2002) Impact of endolithic biofilms on carbonate rock surfaces. In: Siegesmund S, Weiss T, Vollbrecht A (eds) Natural stone, weathering phenomena, conservation strategies and case studies, geological society. Special Publications, London 205:177-194

Porter D, Broxton D, Bass A, Neher DA, Weicht TR, Longmire P, Domingue R (2016) The role of case hardening in the preservation of the cavates and petroglyphs of Bandelier. e-סialogos 5:12-31

Prieto B, Silva B (2005) Estimation of the potential bioreceptivity of granitic rocks from their intrinsic properties. Int Biodeterior Biodegradation 56:206-215

Ramírez M, Hernández-Mariné M, Novelo E, Roldán M (2010) Cyanobacteria containing biofilms from a Mayan monument in Palenque. Mexico Biofouling 26:399-409

Rémazeilles C, Saheb M, Neff D, Guilminot E, Tran K, Bourdoiseau JA, Sabot R, Jeannin M, Matthiesen H, Dillmann P, Refait P (2010) Microbiologically influenced corrosion of archaeological artefacts: characterization of iron(II) sulfides by Raman spectroscopy. J Raman Spectrosc 41:1425-1433

Roberts A, Campbell I, Pring A, Bell G, Watchman A, Popelka-Filcoff R, Lenehan C, Gibson C, Franklin N (2015) A multidisciplinary investigation of a rock coating at Ngaut Ngaut (Devon Downs), South Australia. Aust Archaeol 80:32-39

Rodrigues A, Gutierrez-Patricio S, Miller AZ, Saiz-Jimenez C, Wiley R, Nunes N, Vilarigues M, Macedo MF (2014) Fungal biodeterioration of stained-glass windows. Int Biodeterior Biodegradation 90:152-160

Salvadori O, Casanova A (2016) The role of fungi and lichens in the biodeterioration of stone monuments. Open Conf Proc J 7:39-54

Salvadori O, Charola AE (2011) Methods to prevent biocolonization and recolonization: an overview of current research for architectural and archaeological heritage. In: Charola $\mathrm{AE}$, McNamara C, Koestler RJ (eds) Biocolonization of stone: control and preventive methods. Smithsonian Institute Scholarly Press, Washington, pp 37-50 
Sánchez del Junco A, Moreno DA, Ranninger C, Ortega-Calvo JJ, Saiz-Jimenez C (1992) Microbial induced corrosion of metallic antiquities and works of art: a critical review. Int Biodeterior Biodegradation 29:367-375

Scheerer S (2008) Microbial biodeterioration of outdoor stone monuments. Assessment methods and control strategies. PhD Thesis, Cardiff University, UK

Scheerer S, Ortega-Morales O, Gaylarde C (2009) Microbial deterioration of stone monuments - an updated overview. Adv Appl Microbiol 66:97-139

Shirakawa MA, Tavares RG, Gaylarde CC, Taqueda ME, Loh K, John VM (2010) Climate as the most important factor determining anti-fungal biocide performance in paint films. Sci Total Environ 408:5878-5886

Shirakawa MA, Vanderley MJ, Mocelin A, Zilles R, Toma SH, Araki K, Toma HE, Thomaz AC, Gaylarde CC (2016) Effect of silver nanoparticle and $\mathrm{TiO}_{2}$ coatings on biofilm formation on four types of modern glass. Int Biodeterior Biodegradation 108:175-180

Siegesmund S, Snethlage RE (2014) Stone in architecture. Properties, durability. Springer, Berlin Heidelberg, Germany

Skinner HCW, Jahren AH (2003) Biomineralization. In: Schlesinger WH (ed) Treatise on geochemistry, vol 8. Elsevier, Amsterdam, pp 117-184

Sohrabi M, Favero-Longo SE, Perez-Ortega S, Ascaso C, Haghighat Z, Talebian MH, Fadaei H, de los Ríos A (2017) Lichen colonization and associated deterioration processes in Pasargadae, UNESCO world heritage site, Iran. Int Biodeterior Biodegradation 117:171-182

Sterflinger K (2010) Fungi: their role in deterioration of cultural heritage. Fungal Biol Rev $24: 47-55$

Sterflinger K, Piñar G (2013) Microbial deterioration of cultural heritage and works of art - tilting at windmills? Appl Microbiol Biotechnol 97:9637-9646

Szczepanowska HM, Cavaliere AR (2004) Tutankhamun tomb, a closer look at biodeterioration: preliminary report. In: Rauch A, Miklin-Kniefacz S, Harmssen A (eds) Schimmel: Gefahr für Mensch und Kulturgut durch Mikroorganismen. Konrad Theiss Verlag GmbH \& Co, Stuttgart, pp 42-47

Tescari M, Frangipani E, Caneva G, Casanova Municchia A, Sodo A, Visca P (2018) Arthrobacter agilis and rosy discoloration in "Terme del Foro" (Pompeii, Italy). Int Biodeterior Biodegradation 130:48-54

Tolker-Nielsen T (2015) Biofilm development. Microbiol Spectr 3: MB-0001-2014

Tonon C, Favero-Longo SE, Matteucci E, Piervittori R, Croveri P, Appolonia L, Meirano V, Serino M, Elia D (2019) Microenvironmental features drive the distribution of lichens in the house of the Ancient Hunt, Pompeii, Italy. Int Biodeterior Biodegradation 136:71-81

Traversetti L, Bartoli F, Caneva G (2018) Wind-driven rain as a bioclimatic factor affecting the biological colonization at the archaeological site of Pompeii, Italy. Int Biodeterior Biodegradation 134:31-38

Tretiach M, Pinna D, Grube M (2003) Caloplaca erodens [sect. Pyrenodesmia], a new lichen species from Italy with an unusual thallus type. Mycolog Prog 2:127-136

Unković N, Erić S, Šarić K, Stupar M, Savković Ž, Stanković S, Stanojević O, Dimkić I, Vukojević J, Ljaljević Grbić M (2017) Biogenesis of secondary mycogenic minerals related to wall paintings deterioration process. Micron 100:1-9

Unković N, Dimkić I, Stupar M, Stanković S, Vukojević J, Ljaljević Grbić M (2018) Biodegradative potential of fungal isolates from sacral ambient: in vitro study as risk assessment implication for the conservation of wall paintings. PLoS One 13:e0190922

Urzì C, De Leo F, Bruno L, Pangallo D (2014) New species description, biomineralization processes and biocleaning applications of Roman catacombs-living bacteria. In: Saiz-Jimenez $\mathrm{C}$ (ed) The conservation of subterranean cultural heritage. CRC Press/Balkema, Leiden/Netherlands, pp 65-72

Urzì C, Bruno L, De Leo F (2018) Biodeterioration of paintings in caves, catacombs and other hypogean sites. In: Mitchell R, Clifford J (eds) Biodeterioration and preservation in art, archaeology and architecture. Archetype Publications Ltd, London, pp 114-129 
Vasanthakumar A, DeAraujo A, Mazurek J, Schilling M, Mitchell R (2013) Microbiological survey for analysis of the brown spots on the walls of the tomb of King Tutankhamun. Int Biodeterior Biodegradation 79:56-63

Vázquez-Nion D, Silva B, Prieto B (2018a) Influence of the properties of granitic rocks on their bioreceptivity to subaerial phototrophic biofilms. Sci Total Environ 610-611:44-54

Vázquez-Nion D, Troiano F, Sanmartín P, Valagussa C, Cappitelli F, Prieto B (2018b) Secondary bioreceptivity of granite: effect of salt weathering on subaerial biofilm growth. Mater Struct $51: 158$

Vega LM, Mathieu J, Yang Y, Pyle BH, McLean RJC, Alvarez PJJ (2014) Nickel and cadmium ions inhibit quorum sensing and biofilm formation without affecting viability in Burkholderia multivorans. Int Biodeterior Biodegradation 91:82-87

Videla HA, Herrera LK (2009) Understanding microbial inhibition of corrosion. A comprehensive overview. Int Biodeterior Biodegradation 63:896-900

Viles HA (2012) Microbial geomorphology: a neglected link between life and landscape. Geomorphology 157-158:6-16

Viles HA, Cutler NA (2012) Global environmental change and the biology of heritage structures. Glob Chang Biol 18:2406-2418

Villa F, Pitts B, Lauchnor E, Cappitelli F, Stewart PS (2015) Development of a laboratory model of a phototroph-heterotroph mixed-species biofilm at the stone/air interface. Front Microbiol 6:1251

Villa F, Stewart PS, Klapper I, Jacob JM, Cappitelli F (2016) Subaerial biofilms on outdoor stone monuments: changing the perspective towards an ecological framework. Bioscience 66:285-294

Vítek P, Ascaso C, Artieda O, Wierzchos J (2016) Raman imaging in geomicrobiology: endolithic phototrophic microorganisms in gypsum from the extreme sun irradiation area in the Atacama Desert. Anal Bioanal Chem 408:4083-4092

Wendler E, Prasartet C (1999) Lichen growth on old Khmer-style sandstone monuments in Thailand: damage factor or shelter? In: Bridgland J, Brown J (eds) Proceedings of the 12th triennial meeting of the ICOM Committee for Conservation. James and James, London, pp 750-754

Xu D, Li Y, Gu T (2016) Mechanistic modeling of biocorrosion caused by biofilms of sulfate reducing bacteria and acid producing bacteria. Bioelectrochemistry 110:52-58

Zammit G, De Leo F, Albertano P, Urzì C (2008) A preliminary study of microbial communities colonizing ochre-decorated chambers at the Hal Saflieni Hypogeum at Paola, Malta. In: Lukaszewicz JW, Niemcewicz P (eds) Proceedings of the 11th international congress on deterioration and conservation of stone. Torun, Poland, pp 555-562

Zanardini E, Cappitelli F, Ranalli G, Sorlini C (2008) Biodeterioration processes in relation to cultural heritage materials - metals. In: Caneva G, Nugari MP, Salvadori O (eds) Plant biology for cultural heritage: biodeterioration and conservation. Getty Conservation Institute, Los Angeles, pp 153-156

Zhang G, Gong C, Gu J, Katayama Y, Someya T, Gu JD (2019) Biochemical reactions and mechanisms involved in the biodeterioration of stone world cultural heritage under the tropical climate conditions. Int Biodeterior Biodegradation 143:104723

Zucconi L, Gagliardi M, Isola D, Onofri S, Andaloro MC, Pelosi C, Pogliani P, Selbmann L (2012) Biodeterioration agents dwelling in or on the wall paintings of the Holy Saviour's cave (Vallerano, Italy). Int Biodeterior Biodegradation 70:40-46 
Open Access This chapter is licensed under the terms of the Creative Commons Attribution 4.0 International License (http://creativecommons.org/licenses/by/4.0/), which permits use, sharing, adaptation, distribution and reproduction in any medium or format, as long as you give appropriate credit to the original author(s) and the source, provide a link to the Creative Commons license and indicate if changes were made.

The images or other third party material in this chapter are included in the chapter's Creative Commons license, unless indicated otherwise in a credit line to the material. If material is not included in the chapter's Creative Commons license and your intended use is not permitted by statutory regulation or exceeds the permitted use, you will need to obtain permission directly from the copyright holder. 